\title{
Molybdenum isotope ratios in Izu arc basalts: The control of subduction zone fluids on compositional variations in arc volcanic systems
}

\author{
Javiera Villalobos-Orchard $^{\mathrm{a}, *}$, Heye Freymuth ${ }^{\mathrm{a}, \mathrm{b}}$, Brian O’Driscoll ${ }^{\mathrm{a}}$, Tim Elliott ${ }^{\mathrm{c}}$, \\ Helen Williams ${ }^{b}$, Martina Casalini ${ }^{\mathrm{d}}$, Matthias Willbold ${ }^{\mathrm{a}, \mathrm{e}}$ \\ ${ }^{a}$ Department of Earth and Environmental Sciences, University of Manchester, Oxford Road, M13 9PL Manchester, UK \\ ${ }^{\mathrm{b}}$ Department of Earth Sciences, University of Cambridge, Downing Street, CB2 3EB, Cambridge, UK \\ ${ }^{\mathrm{c}}$ School of Earth Sciences, University of Bristol, Queen's Road, BS8 1RJ Bristol, UK \\ ${ }^{\mathrm{d}}$ University of Florence, Via Giorgio La Pira 4, 50142 Florence, Italy \\ ${ }^{\mathrm{e}}$ Department of Isotope Geology, University of Göttingen, Goldschmidtstr. 1, 37077 Göttingen, Germany
}

Received 31 May 2020; accepted in revised form 30 July 2020; available online 8 August 2020

\begin{abstract}
Molybdenum isotope variations in mafic arc lavas have mainly been attributed to the influence of slab-derived components, such as subducted sediment melts and aqueous fluids. The latter have been hypothesised to fractionate Mo isotopes through interaction with the oceanic crust and carry an isotopically heavy signal that is transferred to the source of arc magmas. Thus, understanding Mo isotope systematics in subduction zones requires characterising the Mo isotope composition of slab-derived fluids and their influence on the Mo isotope budget of arc magmas. However, Mo isotope data reported to date show a considerable influence from subducted sediments that complicate accurate constraints being placed on the fluid contribution. We present Mo isotope data for mafic lavas from the Izu arc, a highly depleted oceanic island arc whose magma compositions show a dominant control from slab-derived fluids. The lavas from the Izu volcanic front are isotopically heavier than MORB and the depleted mantle. Their $\delta^{98 / 95} \mathrm{Mo}$ (the relative difference in measured ${ }^{98} \mathrm{Mo} /{ }^{95} \mathrm{Mo}$ to NIST 3134 ) systematically varies with indicators for fluid-mobile element enrichment, suggesting that slab-derived fluids in the Izu arc have heavy Mo isotope compositions. Additionally, co-variations with radiogenic ${ }^{143} \mathrm{Nd} /{ }^{144} \mathrm{Nd}$ and ${ }^{176} \mathrm{Hf} /{ }^{177} \mathrm{Hf}$ point to a relationship between the addition of aqueous fluids and compositional heterogeneity of the sub-arc mantle. We present mass balance models that show that the influence of subduction zone fluids on the trace element pattern of arc magmas is more dominant when these are added to a more depleted and refractory sub-arc mantle, which preferentially melts due to a relatively higher fluid flux. The mass balance of Mo in the Izu arc predicts a light Mo isotope composition for the residual oceanic crust as a result of the preferential removal of isotopically heavy Mo during slab dehydration, consistent with previous suggestions for the Mariana arc and isotopically light Mo previously reported for eclogites.
\end{abstract}

(C) 2020 Elsevier Ltd. All rights reserved.

Keywords: Molybdenum isotopes; Subduction zones; Arc magmas; Slab fluid; Crustal recycling; Arc mantle

\section{INTRODUCTION}

\footnotetext{
* Corresponding author.

E-mail address: javiera.villalobos.orchard@manchester.ac.uk (J. Villalobos-Orchard).
}

Recent improvements in the analytical precision of Mo isotope data for magmatic rocks (ca. $\pm 0.06 \%$, 2SD in 
$\delta^{98 / 95}$ Mo, e.g. König et al., 2016; Voegelin et al., 2014; Willbold et al., 2016) allow Mo isotopes to be employed as a tracer for petrogenetic processes in subduction zones (Voegelin et al., 2014; Freymuth et al., 2015, 2016a; König et al., 2016; Gaschnig et al., 2017; Wille et al., 2018; Casalini et al., 2019; Zhang et al., 2020). Arc lavas show systematic variations in $\delta^{98 / 95} \mathrm{Mo}$ (defined as the relative difference in measured ${ }^{98} \mathrm{Mo} /{ }^{95} \mathrm{Mo}$ to the NIST 3134 Mo standard) and span a range of $>1.5 \%$, with a weighted average of $0.07 \pm 0.68 \%$ o $(\mathrm{N}=133,2 \mathrm{SD}$; based on data from Voegelin et al., 2014; Freymuth et al., 2015, 2016a; König et al., 2016; Gaschnig et al., 2017; Wille et al., 2018; Casalini et al., 2019; Zhang et al., 2020). This value is systematically higher than that of the depleted mantle and mid-ocean ridge basalts (MORB) at $\delta^{98 / 95} \mathrm{Mo}=$ $-0.21 \pm 0.02 \%$ o (Bezard et al., 2016; Willbold and Elliott, 2017). It has been proposed that high $\delta^{98 / 95}$ Mo values in evolved arc lavas are the result of fractional crystallisation of isotopically light hydrous phases (i.e., amphibole and possibly biotite; Voegelin et al., 2014; Wille et al., 2018). Still, undifferentiated arc lavas that have $\delta^{98 / 95}$ Mo values higher than the depleted mantle are relatively widespread. Therefore, several authors have argued for the additional involvement of slab-derived components to the mantle source of arc basalts to explain the measured range of Mo isotope compositions of primitive arc lavas (Freymuth et al., 2015, 2016a; König et al., 2016; Gaschnig et al., 2017; Casalini et al., 2019; Zhang et al., 2020). Addition of a compositionally diverse subducted sedimentary component to an arc mantle source can explain some of the variation of $\delta^{98 / 95}$ Mo observed for basaltic arc lavas (e.g., Freymuth et al., 2016a; König et al., 2016; Gaschnig et al., 2017; Casalini et al., 2019). Yet, high Mo isotope ratios in comparatively sediment-poor systems require an alternative explanation and have been attributed to the addition of isotopically heavy aqueous slab-derived fluid(s) based on co-variations of Mo isotope ratios and geochemical tracers for subduction zone fluids (Freymuth et al., 2015; König et al., 2016). This is in line with the finding that Mo appears to be mobile in aqueous fluid phases at the conditions relevant for subduction zones (Green and Adam, 2003; König et al., 2010; Bali et al., 2012).

Some current models suggest that such fluids predominantly originate from the dehydration of serpentinites underlying the unaltered portion of the mafic oceanic crust (e.g., Ulmer and Trommsdorff, 1995; see review by Spandler and Pirard, 2013), thus crossing and interacting with the entire oceanic crust before reaching the top of the slab. These models provide a means for the extraction of Mo from the mafic portion of the subducted plate and transfer into the mantle wedge and could potentially lead to the fractionation of Mo isotopes between fluid and residual crust. In the Mariana arc, the offset in $\delta^{98 / 95}$ Mo between the inferred Mo isotope composition of the slab fluid $\left(\delta^{98 / 95} \mathrm{Mo} \sim 0.05 \%\right.$ ) and MORB was suggested to result from retention of isotopically light Mo in residual rutile in the subducted eclogitic crust during the passage of fluids through the subducted plate (Freymuth et al., 2015), a notion that has recently found support from apparent com- plementary low ${ }^{98} \mathrm{Mo} /{ }^{95} \mathrm{Mo}$ measured in eclogites (Chen et al., 2019).

Thus far, all mafic arc lavas for which Mo isotope ratios have been reported show clear signs of multiple influences on their Mo budget (hydrous fluid, subducted sediment, slab melts). Yet, the chemical complexities associated with these arc settings due to the involvement of other slab components do not allow the recognition of any possible effects of fluid-induced melting of the mantle wedge on the Mo isotope variations of the magmas produced.

The Izu arc is a highly depleted arc system, in the sense that the addition of variable amounts of an aqueous fluid dominates the incompatible element inventory of the arc basalts produced (e.g., Taylor and Nesbitt, 1998; Kimura et al., 2010; Freymuth et al., 2016b, 2019). It contains even less input from other slabderived components such as slab melts of altered oceanic crust or sediments compared to the neighbouring Mariana arc. In this respect, the Izu arc is well-suited for elucidating the contribution that slab-derived fluids make to the Mo isotope budget in arc systems in a more controlled manner, as well as to improve our understanding of the mass balance of Mo isotopes in subduction zones. Here we present the first Mo isotope dataset for mafic lavas from the Izu arc. The samples included in this study and the sediment pile subducting beneath the Izu arc (sampled in Ocean Drilling Project (ODP) Site 1149 Leg 185; Plank et al., 2007) are geochemically well-characterised (Freymuth et al., 2016b, 2019 and references therein), offering the advantage of using a combination of Mo isotope ratios and other geochemical data, including radiogenic isotope systems, to establish a solid framework for our interpretations. Specifically, the combined radiogenic and Mo isotope systematics allow us to trace the fluid through the subduction zone system, as well as to investigate the effects of this fluid on the compositional variations observed in basaltic island arc volcanic rocks.

\section{GEOLOGICAL SETTING AND SAMPLE DESCRIPTIONS}

The Izu arc is the northernmost segment of the IzuBonin-Mariana arc in the western Pacific (Fig. 1). The petrogenesis and geochemistry of the Izu arc lavas have been well studied. They originate from a highly depleted mantle source, as shown by their radiogenic ${ }^{143} \mathrm{Nd} /{ }^{144} \mathrm{Nd}$ and ${ }^{176}$. $\mathrm{Hf} /{ }^{177} \mathrm{Hf}$ ratios and high field strength element (HFSE) depletion, where a slightly more isotopically enriched mantle is present towards the rear arc (e.g., Hochstaedter et al., 2000, 2001; Tollstrup et al., 2010; Freymuth et al., 2016b). There is conclusive evidence that the Izu mantle source has been modified by a slab component with a high but variable contribution from slabderived fluids and minimal addition of subducted sediment partial melts (e.g., Taylor and Nesbitt, 1998; Chauvel et al., 2009; Kimura et al., 2010; Tamura et al., 2007; Freymuth et al., 2016b). The lavas from the Izu volcanic front are characterised by high ratios of fluid-mobile to 


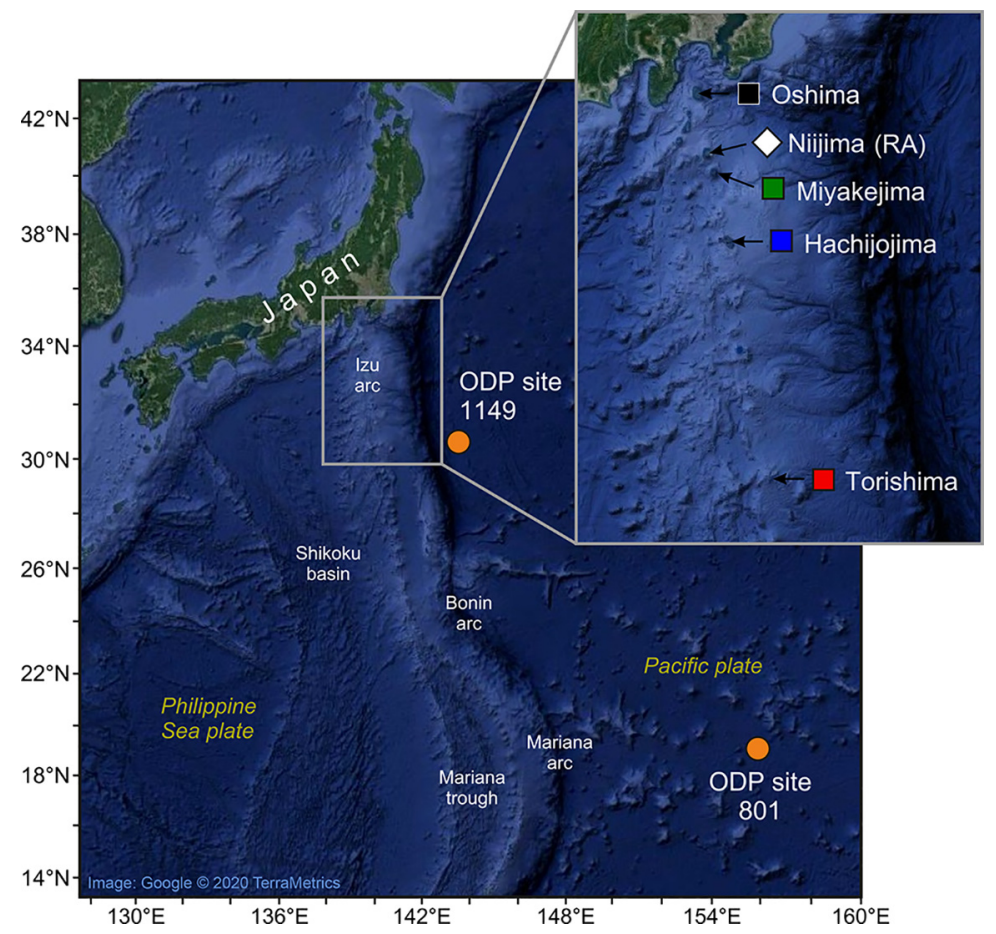

Fig. 1. Map of the Izu arc showing the location of the islands sampled in this study. RA = rear arc.

fluid-immobile elements and excess $\mathrm{U}$ over Th (e.g. Freymuth et al., 2016b), whereas those from the rear arc display moderate signs of fluid contribution and a higher input from slab partial melts (e.g., Taylor and Nesbitt, 1998; Hochstaedter et al., 2001). Accordingly, the Izu volcanic front lavas show variable but high $\mathrm{Ba} / \mathrm{Th}$ and low $\mathrm{La} / \mathrm{Sm}$ ratios. The latter are taken as evidence for high degrees of mantle depletion and melting, and an absence of a sedimentary component, in contrast to lavas from the neighbouring Mariana arc, which have higher $\mathrm{La} / \mathrm{Sm}$ values due to contributions from sediment melts (Elliott et al., 1997). Geochemical intra-island variations in the Izu arc lavas are minimal while inter-island variations are usually distinguishable (e.g., Taylor and Nesbitt, 1998). No major geochemical trends appear to be present along the arc, with the exception of a slight northward enrichment in fluid-mobile elements such as $\mathrm{Ba}, \mathrm{Cs}, \mathrm{Rb}$ and $\mathrm{Pb}$, relative to immobile elements such as $\mathrm{Nb}, \mathrm{Zr}$, and rare earth elements (Taylor and Nesbitt, 1998).

The samples selected for this study come from four islands in the Izu volcanic front: Oshima, Miyakejima, Hachijojima and Torishima, and one island in the Izu rear arc: Niijima. The latter is part of the Zenisu Ridge and located $\sim 15 \mathrm{~km}$ west of the volcanic front, between Oshima and Miyakejima (Fig. 1). The samples are basalts and basaltic andesites from recent $(<10 \mathrm{ka})$ eruptions, either aphyric or porphyritic, with plagioclase and/or olivine phenocrysts, and are in ${ }^{234} \mathrm{U} /{ }^{238} \mathrm{U}$ equilibrium (Freymuth et al., 2016b), indicating that they are free from alteration. Details of sample collection and preparation are reported by Freymuth et al. (2016b) and references therein, together with a geochemical and isotopic characterisation of these samples, including major and selected trace element concentrations, radiogenic $\mathrm{Sr}-\mathrm{Nd}-\mathrm{Hf}$ isotopes, as well as U-series data. More recently, ${ }^{238} \mathrm{U} /{ }^{235} \mathrm{U}$ and $\mathrm{Pb}$ isotope data for the samples have been reported by Freymuth et al. (2019).

\section{ANALYTICAL METHODS}

The Mo isotope compositions of the samples were determined using a double spike MC-ICP-MS technique (e.g. Barling et al., 2001; Siebert et al., 2001; Willbold et al., 2016). A ${ }^{97} \mathrm{Mo}^{100} \mathrm{Mo}$ double spike solution was prepared from enriched ${ }^{97}$ Mo and ${ }^{100}$ Mo tracers obtained in oxide form (Oak Ridge National Laboratories) and calibrated at the University of Bristol using the NIST SRM 3134 Mo isotopic standard based on the procedures described by Rudge et al. (2009). The double spike calibration was tested at the University of Cambridge for inter-laboratory cross calibration by analysing a series of geological reference materials. Furthermore, our ${ }^{97} \mathrm{Mo}-{ }^{100}$ Mo double spike calibration was tested by measuring the NIST SRM 3134 standard and a single digestion of the USGS reference material BHVO-2, with variable spike and sample proportions (see Fig. S1 in supplementary material). Results were indistinguishable within error with double spike proportions between $10-$ and $90 \%$, suggesting accurate calibration of our double spike. Thus, unlike the findings of Zhang et al (2018), the sample/double spike ratio did not affect the accuracy of our measurements, although slightly larger uncertainties were observed at the extremes (Fig. S1). Sample measurements were nevertheless performed with molar sample to double spike proportions ranging near 1:1 to minimise any analytical uncertainty. 
The chemical separation of Mo from the silicate rock matrix followed the protocol described in Willbold et al. (2016) and is briefly described here. About $30-40 \mathrm{mg}$ of sample powder was weighed and mixed with the ${ }^{97} \mathrm{Mo}-{ }^{100}$ Mo double spike solution to achieve a 1:1 molar proportion of Mo in the sample-spike mixture. Samples were then digested in a mixture of $\mathrm{HF} / \mathrm{HNO}_{3} / \mathrm{HCl}$ at $150{ }^{\circ} \mathrm{C}$ for 24 hours on a hotplate, evaporated to dryness and then repeatedly dissolved in several millilitres of $6 \mathrm{M}$ $\mathrm{HCl}$, until total dissolution of the sample was achieved. Usually, 2-3 of these reflux steps were necessary before samples were finally dissolved in $4.5 \mathrm{~mL}$ of $3.33 \mathrm{M} \mathrm{HCl}$. About an hour before loading onto the ion exchange columns, $0.5 \mathrm{~mL} 1 \mathrm{M}$ ascorbic acid was added to the samples. The single column chemistry was carried out employing a $1 \mathrm{~mL}$ bed of Eichrom AG1x8, 100-200 mesh anion exchange resin in Bio-Rad Poly-Prep columns. Afterwards, the samples were dried down and treated twice with $0.1 \mathrm{~mL}$ $\mathrm{HNO}_{3} / \mathrm{H}_{2} \mathrm{O}_{2}$ at $150{ }^{\circ} \mathrm{C}$ for at least 12 hours to decompose organic residues before being taken up in a $0.4 \mathrm{M}$ $\mathrm{HNO}_{3} / 0.05 \mathrm{M} \mathrm{HF}$ solution for analysis.

Measurements were carried out on a ThermoScientific Neptune Plus MC-ICP-MS at the Department of Earth
Sciences, University of Cambridge. The instrument was operated in static, low resolution mode and run under dry plasma conditions whereby samples were introduced into the mass spectrometer at $\sim 50 \mu \mathrm{L} / \mathrm{min}$ using a Teledyne Cetac Aridus II desolvating nebuliser system. In addition to masses 95, 96, 97, 98 and 100 used for the double spike inversion, masses 99 and 101 were monitored for potential isobaric interferences from $\mathrm{Ru}$ on masses 98 and 100. Individual measurements consisted of 30 cycles each, with $4.194 \mathrm{~s}$ integration time. Measurements of samples were bracketed by measurements of spiked NIST SRM 3134 Mo standard to correct for mass drift during analytical sequences, which consisted of ca. 30-40 samples and standards over a time period of 6-7 hours. Data reduction was carried out offline and is based on the mathematical procedure described in Rudge et al. (2009). Final ${ }^{98} \mathrm{Mo} /{ }^{95}$ Mo isotope data are reported as parts per thousand deviations from the NIST SRM 3134 Mo standard (i.e., $\delta^{98 / 95} \mathrm{Mo}_{\text {NIST3134). }}$.

Average $\delta^{98 / 95}$ Mo and Mo concentrations obtained for repeated analyses of geologic reference materials carried out alongside the samples are presented in Table 1 . These values agree well within uncertainty with values reported

Table 1

Mo isotope ratios and Mo concentrations of Izu arc lavas (this study) and selected additional geochemical data (Freymuth et al., 2016b and references therein). Uncertainties in Mo isotope data of Izu arc lavas are presented as 2 standard errors (2SE). Uncertainties for geologic reference materials are 2 standard deviations (2SD). Mo isotope data reported as permil deviations from the NIST 3134 Mo standard.

\begin{tabular}{|c|c|c|c|c|c|c|c|c|c|}
\hline Sample & $\delta^{98 / 95} \mathrm{Mo}$ & $\delta^{98 / 95} \mathrm{Mo}^{*}$ & $2 \mathrm{SE}$ & Mo $[\mu \mathrm{g} / \mathrm{g}]$ & $\mathrm{SiO}_{2}($ wt. $\%)$ & $\mathrm{MgO}(\mathrm{wt} . \%)$ & $\mathrm{Ce}[\mu \mathrm{g} / \mathrm{g}]$ & ${ }^{176} \mathrm{Hf} /{ }^{177} \mathrm{Hf}$ & ${ }^{143} \mathrm{Nd} /{ }^{144} \mathrm{Nd}$ \\
\hline \multicolumn{10}{|l|}{ Oshima } \\
\hline 1986A-1 & 0.11 & 0.10 & 0.04 & 0.68 & 52.12 & 4.80 & 6.42 & 0.283290 & 0.513107 \\
\hline S2-1 & 0.11 & 0.08 & 0.04 & 0.68 & 51.36 & 5.56 & 6.68 & 0.283286 & 0.513107 \\
\hline N4-1 & 0.11 & 0.08 & 0.04 & 0.65 & 52.17 & 5.06 & 7.12 & 0.283289 & 0.513107 \\
\hline Y 5-1 & 0.01 & 0.00 & 0.03 & 0.77 & 52.40 & 4.87 & 6.99 & - & - \\
\hline \multicolumn{10}{|l|}{ Miyakejima } \\
\hline 1469 & -0.02 & -0.03 & 0.04 & 0.90 & 53.55 & 4.55 & 10.80 & 0.283262 & 0.513106 \\
\hline $1983-2903$ & -0.02 & -0.03 & 0.04 & 0.92 & 53.30 & 4.02 & 9.96 & 0.283263 & 0.513108 \\
\hline MJ-12-02 & 0.01 & -0.02 & 0.04 & 0.82 & 53.13 & 3.91 & 10.13 & 0.283261 & 0.513105 \\
\hline 1874 & 0.00 & -0.04 & 0.04 & 0.86 & 54.03 & 4.09 & 10.90 & - & $0.513111^{\mathrm{a}}$ \\
\hline \multicolumn{10}{|l|}{ Hachijojima } \\
\hline $03102812 \mathrm{~A}$ & -0.06 & -0.07 & 0.04 & 0.78 & 50.57 & 3.62 & 8.11 & 0.283236 & 0.513101 \\
\hline 03103009 & -0.04 & -0.07 & 0.03 & 0.79 & 50.76 & 4.00 & 8.10 & 0.283226 & 0.513096 \\
\hline 03102804 & -0.03 & -0.05 & 0.04 & 1.10 & 52.41 & 4.07 & 10.30 & 0.283234 & 0.513102 \\
\hline 03102807 & -0.13 & -0.14 & 0.04 & 0.78 & 51.04 & 3.74 & 8.75 & - & $0.513089^{b}$ \\
\hline \multicolumn{10}{|l|}{ Torishima } \\
\hline TS-01-01 (1) & 0.07 & 0.04 & 0.04 & 0.77 & 51.80 & 3.38 & 4.86 & 0.283277 & 0.513118 \\
\hline TS-17-24 (24) & 0.04 & 0.01 & 0.04 & 0.87 & 54.66 & 4.08 & 5.88 & 0.283272 & 0.513111 \\
\hline \multicolumn{10}{|l|}{ Niijima } \\
\hline NJ-1 & -0.14 & -0.17 & 0.03 & 0.38 & 51.29 & 5.03 & 11.36 & 0.283230 & 0.513060 \\
\hline $\mathrm{NJ}-2$ & -0.09 & -0.12 & 0.03 & 0.38 & 51.03 & 4.91 & 10.38 & 0.283229 & 0.513068 \\
\hline Reference material & $\mathrm{n}$ & $\delta^{98 / 95} \mathrm{Mo}$ & $2 \mathrm{SD}$ & Mo $[\mu \mathrm{g} / \mathrm{g}]$ & $2 \mathrm{SD}$ & & & & \\
\hline BHVO-2 & 10 & -0.05 & 0.09 & 4.62 & 2.66 & & & & \\
\hline JB-2 & 8 & 0.06 & 0.04 & 0.94 & 0.26 & & & & \\
\hline AGV-2 & 8 & -0.15 & 0.05 & 1.92 & 0.28 & & & & \\
\hline SBC-1 & 3 & 0.41 & 0.04 & 2.14 & 0.22 & & & & \\
\hline
\end{tabular}

\footnotetext{
* Blank corrected.

a From Fukuda et al. (2008).

b From Ishizuka et al. (2008).
} 
by other studies, where such data are available (e.g., Freymuth et al., 2015; König et al., 2016; Voegelin et al., 2014; Willbold et al., 2016; Casalini et al., 2019). The reference material BHVO-2 has been found to have a heterogeneous Mo concentration and possibly isotopic composition (Burkhardt et al., 2014; Freymuth et al., 2015; Yang et al., 2015; Willbold et al., 2016). We therefore consider the GSJ reference material JB-2, which is a basaltic material from Oshima (Imai et al., 1995), a better representative of the overall uncertainty of our methodological setup. Full procedural blanks ranged between 240 and 460 pg Mo and correspond to less than $1.5 \%$ of the Mo content of the processed samples. A blank correction was applied to all samples, though blank-corrected and uncorrected $\delta^{98 / 95}$ Mo values are identical within 2 standard error (2SE) uncertainties (Table 1).

\section{RESULTS}

Mo isotope data and concentrations for the Izu arc lavas are presented in Table 1 . Mo abundances and $\delta{ }^{98 / 95}$ Mo do not show systematic co-variation within the Izu arc front (i.e., Oshima, Miyakejima, Hachijojima and Torishima), although differences in Mo abundances and $\delta^{98 / 95}$ Mo are observed between the Izu volcanic front and the rear arc samples (i.e., Niijima). Molybdenum concentrations of samples from islands in the volcanic front vary over a rela- tively narrow range (average of $0.81 \pm 0.22 \mu \mathrm{g} / \mathrm{g} ; 2 \mathrm{SD}$ ) and are higher by a factor of two than samples from the rear arc and MORB (Fig. 2) despite similar degrees of differentiation (Fig. 3). In terms of their Mo isotope ratios, samples from the volcanic front have significantly higher $\delta^{98 / 95} \mathrm{Mo}$ than MORB and the depleted mantle, while rear arc samples have the lowest $\delta^{98 / 95}$ Mo and overlap with the range of MORB. The Mo isotope ratios of the Izu arc lavas thus extend over similar values to samples from the neighbouring Mariana arc, for which a range between -0.10 and $0.07 \%$ has been reported (Freymuth et al., 2015) and are at the high end of $\delta^{98 / 95} \mathrm{Mo}$ values reported for rocks with mafic composition in other arc systems (Voegelin et al., 2014; König et al., 2016; Gaschnig et al., 2017; Wille et al., 2018).

There are distinct Mo isotope compositions between all the different islands, and variations in $\delta^{98 / 95} \mathrm{Mo}$ and Mo contents within islands are small: Miyakejima ( $n=4$ samples) yields particularly homogeneous Mo isotope ratios and concentrations, with $\delta^{98 / 95}$ Mo ranging from -0.04 to $-0.02 \%$, whereas samples from Oshima ( $\mathrm{n}=4$ samples) and Hachijojima $(\mathrm{n}=4$ samples) have higher intra-island heterogeneity in $\delta^{98 / 95} \mathrm{Mo}$, which span a range from 0.00 to $0.10 \%$ and -0.14 to $-0.05 \%$, respectively. Inter-island variations in Mo isotope ratios do not show a geographical trend, similar to what has been observed for trace element behaviours in lavas of similar age in the Izu arc (e.g.,

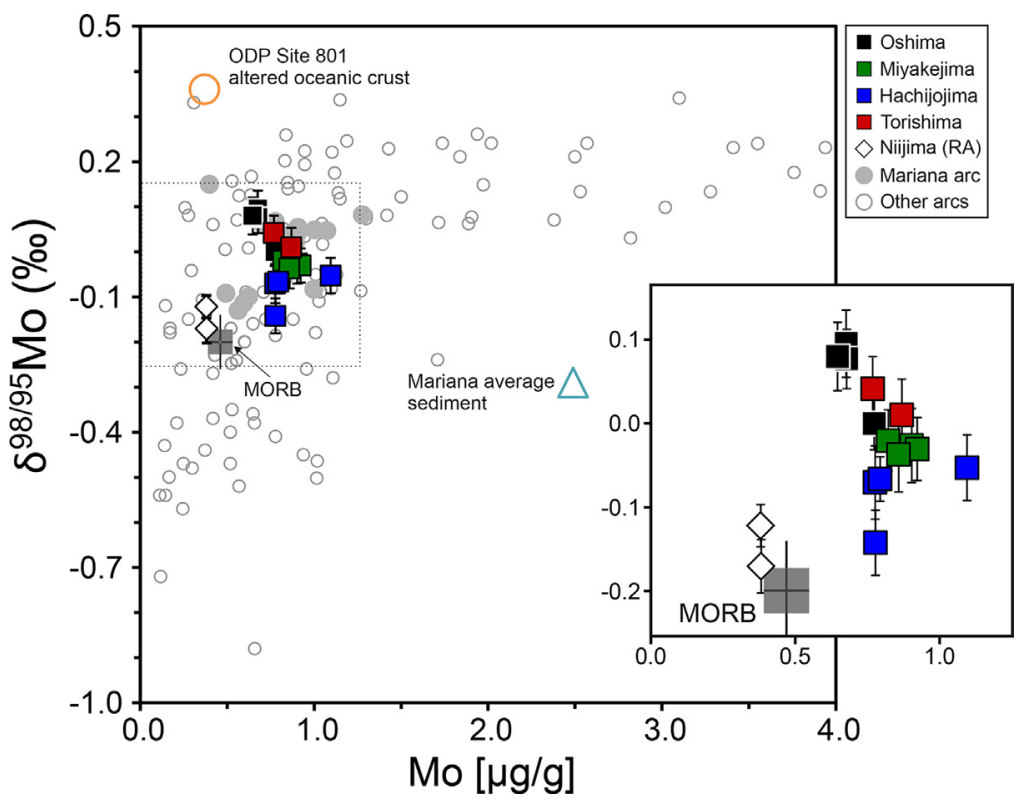

Fig. 2. Mo isotope ratios versus Mo concentrations in the Izu arc lavas and published data for arc lavas from the Mariana (Freymuth et al., 2015) and other volcanic arcs (Solomon/Bismarck and Cyprus (König et al., 2016), Aegean (Voegelin et al., 2014), Lesser Antilles (Freymuth et al., 2016a; Gaschnig et al., 2017), Banda (Wille et al., 2018), Tuscany/Vesuvius (Casalini et al., 2019) and North Tianshan (Zhang et al., 2020); some datapoints plot off the scale). Mo data for MORB, ODP Site 801 altered mafic oceanic crust and average Mariana sediment (ODP Sites $800,801,802)$ from Freymuth et al. (2015) shown for reference. Inset shows samples of this study and MORB as an enlargement of area indicated by dashed box. 


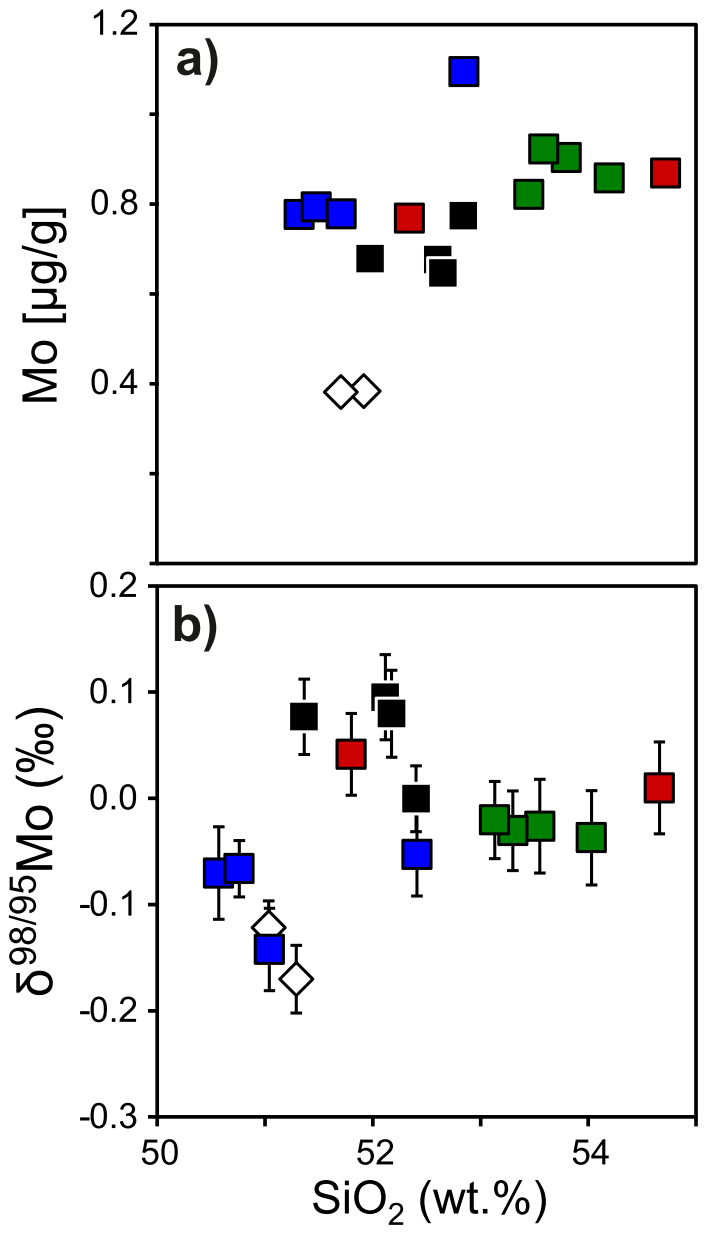

Fig. 3. (a) Mo concentrations and (b) Mo isotope ratios of Izu arc lavas with respect to $\mathrm{SiO}_{2}$. Major elements data are from Freymuth et al. (2016b). Symbols are the same as in Fig. 1.

Freymuth et al., 2016b; Kimura et al., 2010; Tamura et al., 2007; Taylor and Nesbitt, 1998).

\section{DISCUSSION}

\subsection{Effects of magmatic differentiation on Mo isotope variations}

Fractional crystallisation of amphibole during magmatic differentiation has been suggested as a possible mechanism to explain heavy Mo isotope ratios in differentiated arc lavas (Voegelin et al., 2014; Wille et al., 2018). Molybdenum concentrations in the Izu arc lavas show a slight increase with $\mathrm{SiO}_{2}$ content (Fig. 3) and a decrease with $\mathrm{MgO}$ (Fig. S2), suggesting moderately incompatible behaviour of Mo during differentiation, similar to the light rare earth elements (Fig. S3). However, Mo isotope ratios do not vary systematically with $\mathrm{SiO}_{2}$ content nor $\mathrm{MgO}$, indicating that fractional crystallisation processes are not responsible for the observed Mo isotope variations. Fractionation of amphibole from evolving magmas would produce low $\mathrm{Dy} / \mathrm{Yb}$ and high $\mathrm{La} /$ $\mathrm{Yb}$ ratios in the residual melt (e.g., Davidson et al., 2007; Wille et al., 2018). Therefore, if fractionated amphibole would have scavenged isotopically light Mo, a correlation between these trace element ratios and $\delta^{98 / 95}$ Mo would be expected, but is not observed (Fig. S4). Furthermore, our data display a positive trend between both ${ }^{143} \mathrm{Nd} /{ }^{144} \mathrm{Nd}$ and ${ }^{176} \mathrm{Hf} /{ }^{177} \mathrm{Hf}$ isotope ratios and mass-dependent Mo isotope variations (Fig. 4), whereby samples with mantle-like $\delta^{98 / 95}$ Mo also have the most unradiogenic ${ }^{143} \mathrm{Nd} /{ }^{144} \mathrm{Nd}$ and ${ }^{176} \mathrm{Hf} /{ }^{177} \mathrm{Hf}$ values. This also suggests that the relatively high $\delta^{98 / 95}$ Mo values in our mafic sample suite are not the result of fractional crystallisation of amphibole in the lower arc crust (Wille et al., 2018; Davidson et al., 2007), in line with findings from other Mo isotope studies on mafic lavas (Freymuth et al., 2015; Yang et al., 2015; König et al., 2016).

\subsection{Slab contributions to the Mo budget of the Izu arc magmas}

Enrichment in incompatible elements is a distinctive geochemical feature of arc magmas and is assumed to reflect
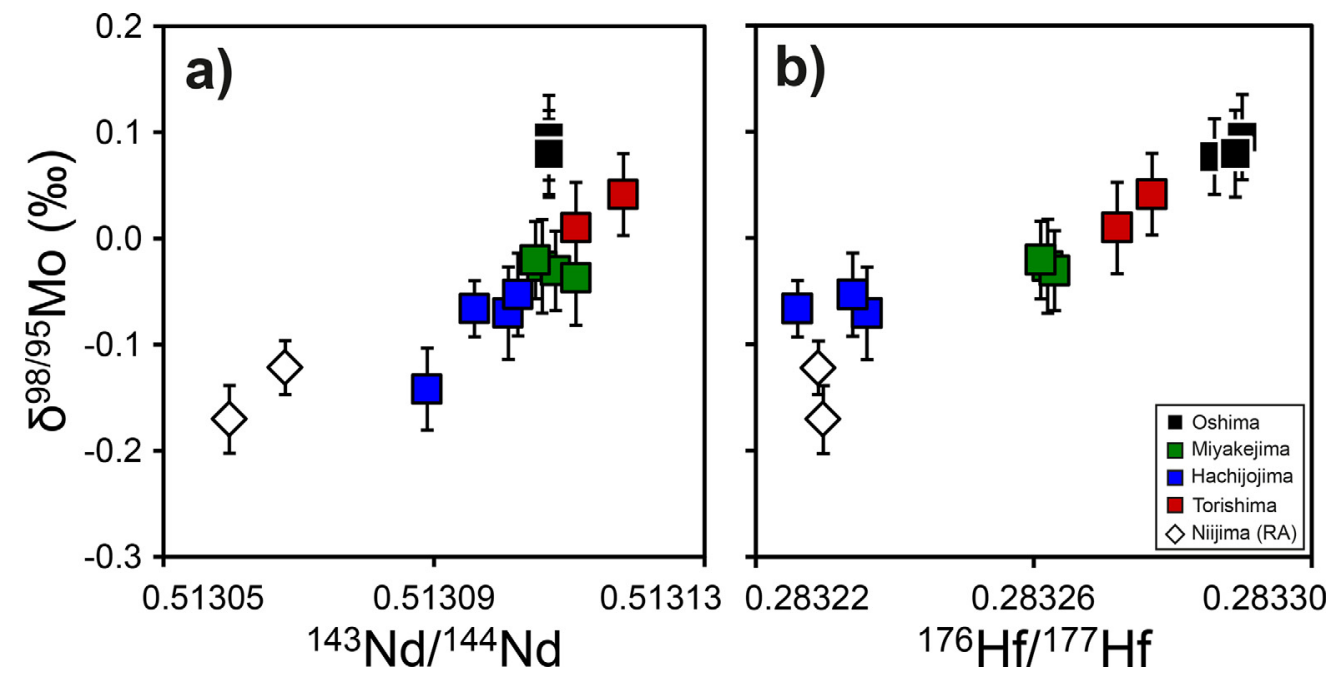

Fig. 4. Mo isotope ratios in the Izu arc lavas against (a) ${ }^{143} \mathrm{Nd} /{ }^{144} \mathrm{Nd}$ and (b) ${ }^{176} \mathrm{Hf} /{ }^{177} \mathrm{Hf}$ isotope ratios. ${ }^{176} \mathrm{Hf} /{ }^{177} \mathrm{Hf}$ and ${ }^{143} \mathrm{Nd} /{ }^{144} \mathrm{Nd}$ isotope data are from Freymuth et al. (2016b). 
incorporation of slab-derived material, such as aqueous fluids and partial melts from sediment and altered oceanic crust, into their mantle source (e.g., Gill, 1981; Hawkesworth et al., 1991; Elliott et al., 1997; Spandler and Pirard, 2013). For the Izu arc, markers for sediment input in arc magmas, such as $\mathrm{La} / \mathrm{Sm}$ ratios, are not correlated with Mo isotope ratios (Fig. 5a). Similarly, no correlation is observed with Th isotope ratios (Fig. S5), which have been suggested as tracers for mafic slab components in the Izu arc lavas (Freymuth et al., 2016b). On the other hand, Mo isotope ratios in the Izu arc lavas display systematic co-variations with $\mathrm{Ce} / \mathrm{Pb}$, $\mathrm{Ba} / \mathrm{Th}$ and U-excess (see Fig. 5b, 5c and 6a). Samples from Oshima, which show the lowest $\mathrm{Ce} / \mathrm{Pb}$, the highest $\mathrm{Ba} / \mathrm{Th}$ and the highest activity ratios in $\left({ }^{238} \mathrm{U} /{ }^{230} \mathrm{Th}\right)$, also display the highest $\delta^{98 / 95}$ Mo values.

The co-variations of Mo isotope ratios with $\mathrm{Ba} / \mathrm{Th}$ and $\left({ }^{238} \mathrm{U} /{ }^{230} \mathrm{Th}\right)$ (Fig. 5) indicate contributions from at least two geochemically distinct sources. The high $\delta^{98 / 95} \mathrm{Mo}$ component is associated with high $\mathrm{Ba} / \mathrm{Th}$ and excess $\mathrm{U}$ (Fig. 5). This could, in principle, be generated by melting of altered mafic oceanic crust (AMOC), which also has elevated $\delta^{98 / 95}$ Mo. Some experimental studies have suggested that the presence of residual allanite during slab melting might cause trace element fractionations similar to those produced by aqueous fluids (Klimm et al., 2008), although it has more recently been shown that allanite and monazite are not likely to be stable residual phases during melting of natural slab compositions (Skora and Blundy, 2010). It has also been suggested that AMOC partial melts with a Thenriched epidote-bearing residue (Carter et al. 2015) could develop elevated $\mathrm{Ba} / \mathrm{Th}$ and $\left({ }^{238} \mathrm{U} /{ }^{230} \mathrm{Th}\right)$. However, the latter scenario is inconsistent with Th mobilisation from the slab as indicated by $\mathrm{Th}$ isotope ratios in the Izu arc lavas (Freymuth et al., 2016b). Furthermore, the high Ba/Th component is associated with $\mathrm{Pb}$ isotope ratios similar to unaltered MORB in the Izu arc (as well as the adjacent
Mariana arc; Freymuth et al., 2015), precluding its derivation from the AMOC, which has relatively elevated ${ }^{206} \mathrm{~Pb} /{ }^{204} \mathrm{~Pb}$ (see discussion in Freymuth et al., 2016b, 2019).

On the basis of the above arguments, we therefore interpret the elevated $\mathrm{Ba} / \mathrm{Th}$, U-excess and heavy Mo isotope ratios in the Izu arc lavas to be the result of the addition of aqueous fluids rather than melts of the AMOC. This is in line with previous studies that suggested dominant contributions from slab-derived fluids to the Izu arc mantle source (e.g., Freymuth et al., 2016b; Kimura et al., 2010; Tamura et al., 2007; Taylor and Nesbitt, 1998). We envision these fluids to be generated from the dehydration of serpentinised mantle below the mafic oceanic crust (e.g., Ulmer and Trommsdorff, 1995; Spandler and Pirard, 2013). This allows them to acquire an unradiogenic $\mathrm{Pb}$ isotope composition from largely unaltered, lower levels of the mafic oceanic crust. This part of the mafic crust has also been previously suggested as the source for isotopically heavy Mo and isotopically light $\mathrm{U}$ in the fluids, whose signatures are generated by interaction with rutile and epidote, respectively (Freymuth et al., 2015, 2019). The low $\delta^{98 / 95}$ Mo component, with trace element and Mo isotope ratios closer to those of the depleted mantle (Fig. 5), is represented by the samples from Niijima in the Izu rear arc, which have been associated with relatively minor contributions from aqueous fluids and higher input from slab melts compared to the arc front magmas (Freymuth et al., 2016b; Kimura et al., 2010; Taylor and Nesbitt, 1998).

A striking observation from our new data is that the covariations between Mo isotope ratios and some fluid addition indices, such as $\mathrm{Ba} / \mathrm{Th}$, are less pronounced than those between $\delta^{98 / 95}$ Mo and radiogenic isotopes, in particular ${ }^{176}$. $\mathrm{Hf} /{ }^{177} \mathrm{Hf}$. On the other hand, $\mathrm{Hf}$ and $\mathrm{Nd}$ isotope ratios in the Izu arc lavas co-vary negatively with some of these fluid signatures (Fig. S6), revealing an underlying relationship between the addition of subduction zone fluids and possible

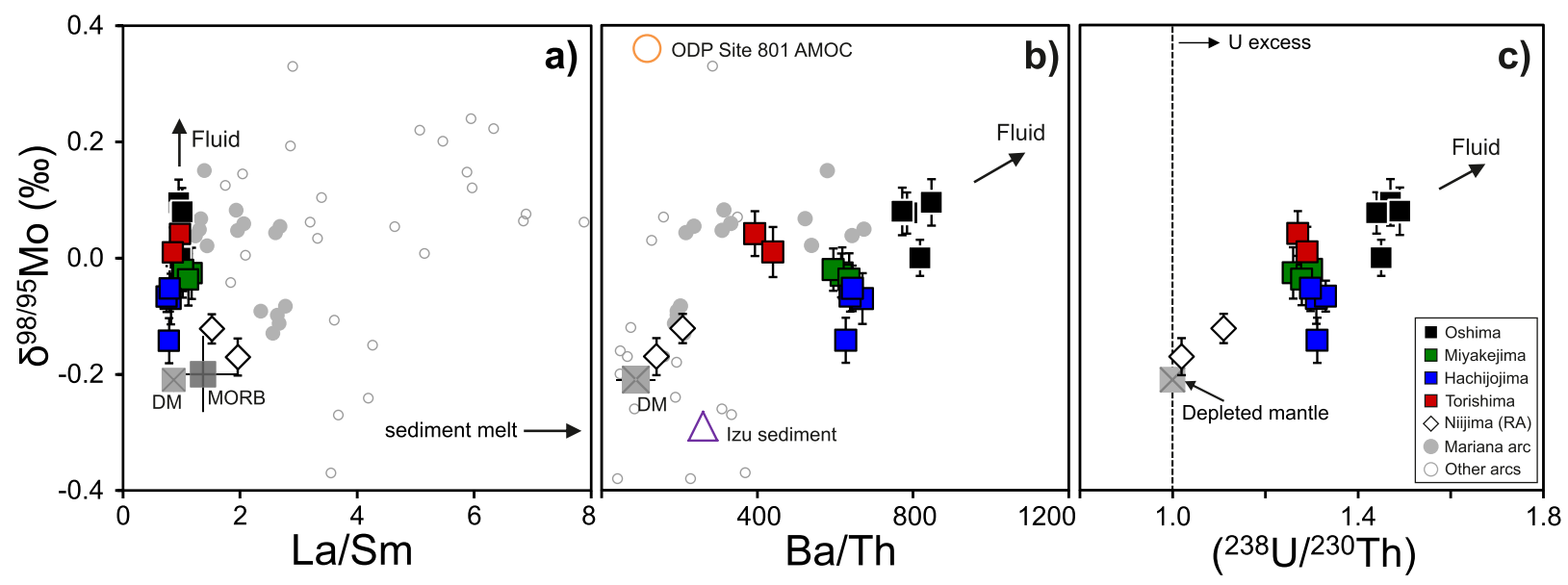

Fig. 5. Mo isotope ratios in the Izu arc lavas plotted versus: (a) $\mathrm{La} / \mathrm{Sm}$, (b) $\mathrm{Ba} / \mathrm{Th}$, and (c) $\left({ }^{238} \mathrm{U} /{ }^{230} \mathrm{Th}\right.$ ). Trace element data for Izu samples are from Freymuth et al. (2016b). Samples from the Mariana (grey circles) and other arcs (white circles), MORB (dark grey cross), the depleted mantle (DM, light grey cross), Izu subducted sediment (purple triangle, estimated; see Table 2) and altered mafic oceanic crust (AMOC; orange circle) are shown for reference. Data sources as in Fig. 2. Mo isotope data for the depleted mantle are from Bezard et al. (2016) and trace element abundances are from Salters and Stracke (2004). Black arrows indicate the direction of fluid and sediment melt addition. (For interpretation of the references to colour in this figure legend, the reader is referred to the web version of this article.) 
variations in the mantle source composition of the Izu arc lavas. We will discuss possible mechanisms that could explain the observed co-variations below (see Section 5.3).

Molybdenum mobilisation and transfer from the subducted slab into the overlying mantle wedge via slabderived fluid(s) should result in Mo enrichment in arc magmas. This enrichment is not necessarily observed in the absolute Mo content of the lavas, which may also be influenced by magmatic differentiation and the degree of depletion of the mantle source. However, Mo transfer in slab fluids can be traced by comparing its abundances to similarly incompatible, but less fluid-mobile elements, such as $\mathrm{Ce}$ and Pr (Newsom and Palme, 1984; Newsom et al., 1986). Low Ce/Mo ratios in lavas have been used in other volcanic arcs to identify the contribution of slab fluids to the Mo content and Mo isotope budget of island arc sources (Freymuth et al., 2015, 2016a; König et al., 2016). The samples from the Izu volcanic front have some of the lowest $\mathrm{Ce} / \mathrm{Mo}$ ratios among arc lavas analysed so far (Fig. 6b), highlighting the dominant influence of the slabderived fluids. Yet, in detail, the inter-island patterns in various indicators for fluid addition differ when plotted against Mo isotope ratios (Figs. 5b, c and 6a, b), suggesting some additional complexity such as minor heterogeneities in the fluid $\delta^{98 / 95} \mathrm{Mo}$ or fluid Ce/Mo. Given that fluid-sensitive trace element ratios and isotope systematics broadly vary along the Izu arc (Freymuth et al., 2016b; also see Fig. 5), it is conceivable that the fluxes of fluids being released from the serpentinites are subtly variable, possibly indicative of different depths. This would result in slightly different fluid compositions entering the overlying subducted crust potentially leading, in turn, to $\mathrm{Ce} / \mathrm{Mo}$ ratios that are buffered in the Izu volcanic front lavas $(\mathrm{Ce} / \mathrm{Mo}=10.1 \pm 3.6(2 \mathrm{SD})$; see Fig. 6b). Partitioning of Mo appears to depend on the chlorine content of the fluid and decreases with lower salinity (Bali et al., 2012). In addition, oxygen fugacity plays an important role in the mobility of Mo, as Mo is more readily partitioned into oxidised aqueous fluids, and it also affects the stability of residual minerals, such as rutile, which preferentially incorporates Mo (Bali et al., 2012; Skora et al., 2017). In the case of the Izu arc lavas, it is possible that small changes in salinity and/or oxygen fugacity as a function of the amount of fluid passing through the crust buffer the $\mathrm{Ce} / \mathrm{Mo}$ in the slab-derived fluid. If true, this would mean that, with increasing fluid flux, fluids interacting with the crust might be more oxidised and have lower salinity, leading to a higher stability of rutile, and hence to higher $\delta^{98 / 95}$ Mo. At the same time, it is plausible these fluidcrust interactions would maintain a somewhat constant Mo concentration in the fluid as a result of the trade-off between increasing oxygen fugacity and lowering salinity. In contrast, $\mathrm{Pb}$ concentrations and the $\mathrm{Ce} / \mathrm{Pb}$ ratio should be less susceptible to such variations and record more faithfully the relative amounts of fluids added to the source of the arc lavas (Miller et al., 1994), especially when such fluids have overall low salinities (Rustioni et al., 2019). Approximating the fluid to $\mathrm{Ce} / \mathrm{Pb} \sim 0$ might thus be a more reliable parameter for examining the Mo isotope composition of subduction zone fluids. From inspection of the data in Fig. 6, it is apparent that the fluid component must be at

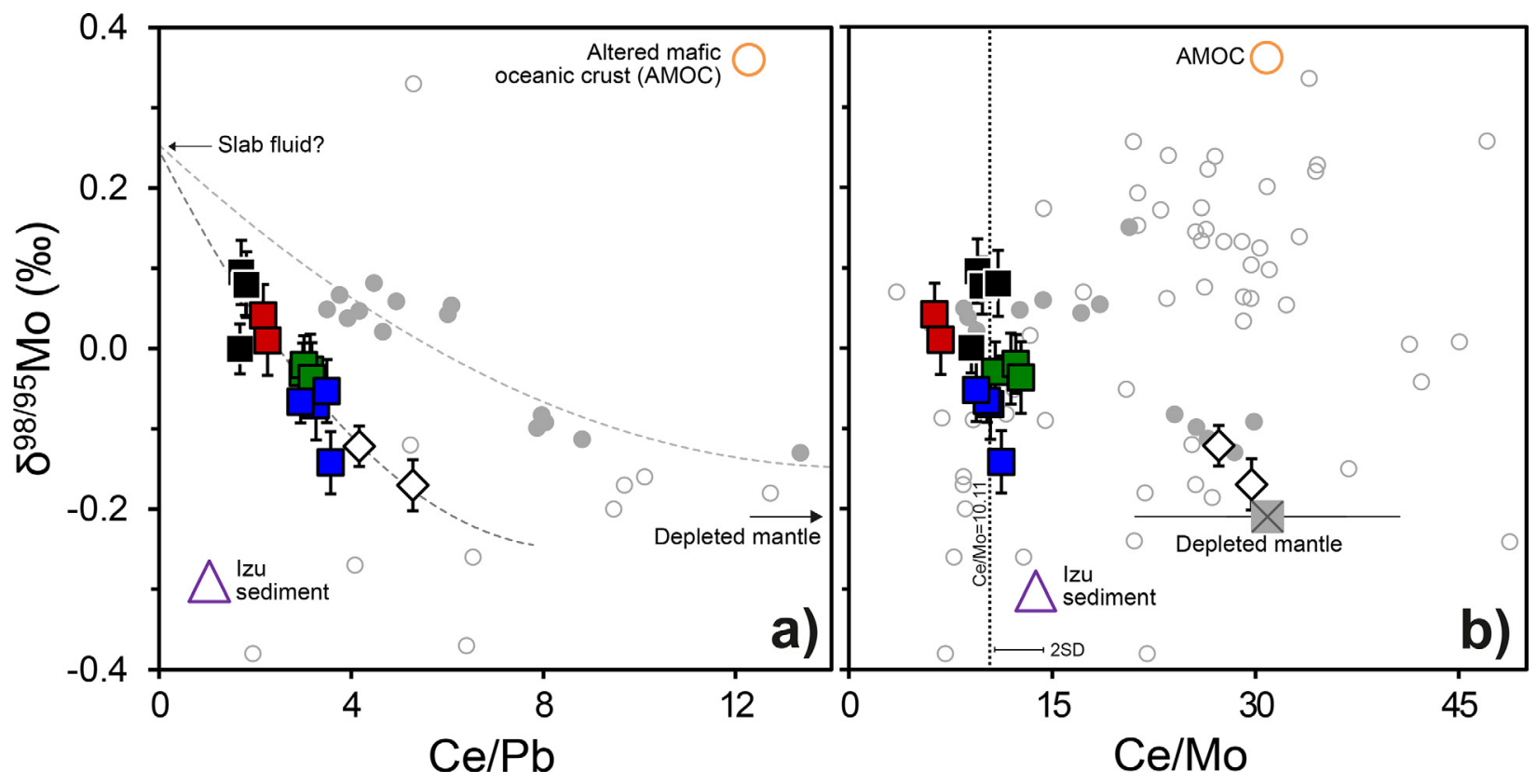

Fig. 6. Mo isotope ratios of Izu arc samples versus: (a) $\mathrm{Ce} / \mathrm{Pb}$. Dashed lines show quadratic regression trends through the Izu and Mariana arc lavas, suggesting a maximum $\delta^{98 / 95}$ Mo of $\sim 0.25 \%$ for the slab-derived fluid. (b) Ce/Mo. Pointed line is the average Ce/Mo of the Izu volcanic front lavas $(\mathrm{Ce} / \mathrm{Mo}=10.11) ; 2 \sigma$ standard deviation shown at the bottom. Data from the Mariana (grey circles) and other arcs (white circles), depleted mantle (grey cross), altered mafic oceanic crust (orange circle) and Izu subducted sediment (purple triangle, estimated; see Table 2) are shown for reference. Data sources as in Fig. 2 and depleted mantle as in Fig. 5. Trace element data for Izu samples are from Freymuth et al. (2016b). (For interpretation of the references to colour in this figure legend, the reader is referred to the web version of this article.) 
least as isotopically heavy as the sample with the highest Mo isotope ratio (i.e., sample 1986A-1 from Oshima; $\delta^{98 / 95}$ $\mathrm{Mo} \geq 0.1 \%$ ), but it might be as high as $\delta^{98 / 95} \mathrm{Mo}=0.25 \%$ (Fig. 6a). The range proposed here gives a higher estimation for the Mo isotope composition of slab-derived fluids than the estimates produced at the Lesser Antilles $\left(\delta^{98 / 95}\right.$ Mo -0.15\%; Freymuth et al., 2016a) and Mariana $\left(\delta^{98 / 95}\right.$ Mo $\sim 0.05 \%$; Freymuth et al., 2015) arcs, which have been shown to incorporate various proportions of additional slab components.

\subsection{A sub-arc mantle control on Mo isotope variations in the Izu arc lavas}

The Izu arc samples have ${ }^{143} \mathrm{Nd} /{ }^{144} \mathrm{Nd}$ and ${ }^{176} \mathrm{Hf} /{ }^{177} \mathrm{Hf}$ ratios that exhibit affinities with Indian MORB (e.g. Tollstrup et al., 2010, Freymuth et al., 2016b, Fig. 7). In ${ }^{176} \mathrm{Hf} /{ }^{177} \mathrm{Hf}$ versus ${ }^{143} \mathrm{Nd} /{ }^{144} \mathrm{Nd}$ space, they are also similar to basalts from the Shikoku basin and the Mariana Trough (the back-arc basins to the Izu and Mariana arcs, respectively; see Fig. 1), which directly reflect the compositional variation of the mantle underlying the Izu-Bonin-Mariana arc system (Woodhead et al., 2012). This suggests that the ${ }^{143} \mathrm{Nd} /{ }^{144} \mathrm{Nd}-{ }^{176} \mathrm{Hf} /{ }^{177} \mathrm{Hf}$ inventory in the Izu arc magmas is dominated by contributions from the mantle wedge rather than by input from the subducted slab (e.g., Taylor and Nesbitt, 1998; Chauvel et al., 2009; Freymuth et al., 2016b). Molybdenum isotope ratios in the Izu arc lavas show a co-variation with radiogenic
${ }^{143} \mathrm{Nd} /{ }^{144} \mathrm{Nd}$ and ${ }^{176} \mathrm{Hf} /{ }^{177} \mathrm{Hf}$ ratios (Fig. 4), whereby more fluid-rich samples (i.e., with higher $\delta^{98 / 95} \mathrm{Mo}$ and lower Ce/ $\mathrm{Pb}$ ) are associated with more depleted mantle-like compositions in terms of ${ }^{143} \mathrm{Nd} /{ }^{144} \mathrm{Nd}$ and ${ }^{176} \mathrm{Hf} /{ }^{177} \mathrm{Hf}$. This points to a key underpinning relationship between the addition of a slab fluid and the variability in radiogenic isotopes observed in the Izu arc basalts, linking the sub-arc mantle composition to their Mo isotope systematics.

The chemical composition of the Izu arc mantle has been shown to be heterogeneous on an arc-length scale on the basis of $\mathrm{Sr}-\mathrm{Nd}-\mathrm{Hf}-\mathrm{Pb}$ isotope systematics (Hochstaedter et al., 2001; Tollstrup et al., 2010; Kimura et al., 2010; Freymuth et al., 2016b) and seismic data (Isse et al., 2009). In the case of our sample set, the mantle underlying the central sections (Miyakejima and Hachijojima) is geochemically less depleted than that in the northern (Oshima) and southern sections (Torishima) of the arc. Mantle heterogeneity should not only be reflected in the radiogenic isotope ratios of the associated lavas, but also in their trace element abundances; in particular, the degree of depletion of incompatible elements. The introduction of trace elements via fluids transferred from the subducting slab to the sub-arc mantle would, therefore, have a more pronounced effect on the chemical composition of magmas produced in highly depleted mantle sections, especially for elements that are mantle-incompatible and fluid-mobile, such as $\mathrm{Ba}, \mathrm{Pb}$ and $\mathrm{Mo}$. On the other hand, such interactions could result in different degrees of fluid-induced melting, with low fluid fluxes leading to melting of more

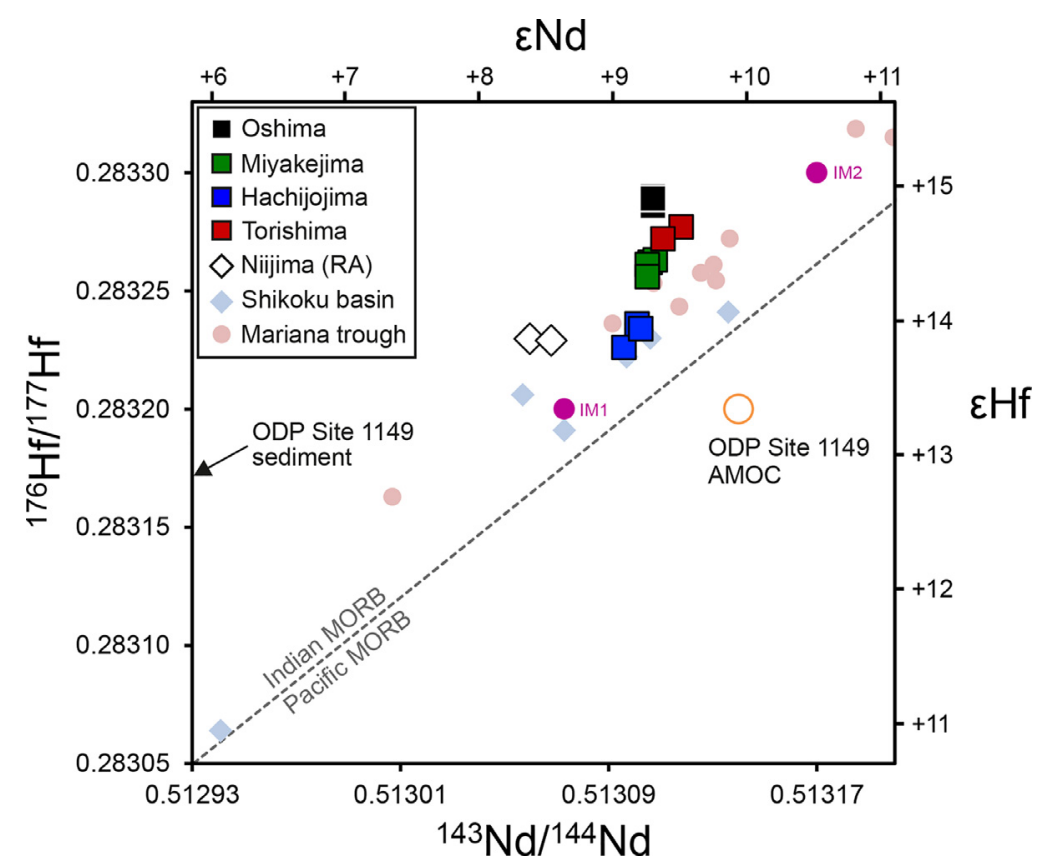

Fig. 7. ${ }^{176} \mathrm{Hf} /{ }^{177} \mathrm{Hf}$ and ${ }^{143} \mathrm{Nd} /{ }^{144} \mathrm{Nd}$ isotope data for the Izu arc lavas (Freymuth et al., 2016b), Mariana Trough (light pink circles; Woodhead et al., 2012) and Shikoku basin (light blue diamonds; Straub et al., 2010; Tollstrup et al., 2010) basalts. Data for ODP Site 1149 sediment (shown in Table 2; Chauvel et al., 2009) and altered mafic oceanic crust (open orange circle; Miyazaki et al., 2015) are included for reference. The Indian-Pacific MORB discriminatory line is from Pearce et al. (1999). Mantle end-members IM1 and IM2 used for modelling are shown in magenta circles (see text and Table 2 for details). (For interpretation of the references to colour in this figure legend, the reader is referred to the web version of this article.) 
enriched (i.e. fertile) mantle components and higher fluid flux leading to expansion of melting to more depleted components.

In the context of the arguments above, we explored the Mo-Nd-Hf isotopic variability of the Izu arc magmas through a simple geochemical model. To avoid introducing additional complexity to our model, we considered only the samples from the Izu volcanic front (see Table 1), because the slab component at the Izu rear-arc has an overall different composition (e.g. Hochstaedter et al., 2001; Tollstrup et al., 2010; Kimura et al., 2010; Freymuth et al., 2016b). We assumed a mantle source with heterogeneous ${ }^{143} \mathrm{Nd} /{ }^{144} \mathrm{Nd}$ and ${ }^{176} \mathrm{Hf} /{ }^{177} \mathrm{Hf}$ composition, to which a slab-derived component with different proportions of aqueous fluid is added. To appreciate the full spectrum of possible slab components, we also allow for the addition of partial melts of subducted sediment, as well as an AMOC component, in a similar manner to Freymuth et al. (2016b). As discussed in the previous section, a fluid-dominated slab contribution controls the Mo budget of the Izu arc lavas. Characterising the composition of the slab-derived fluid requires initial assumptions concerning the conditions of fluid release and Mo mobilisation. Based on the considerations set out previously, we assumed an oxidised aqueous fluid $\left(f \mathrm{O}_{2}=\right.$

FMQ + 4 upon antigorite breakdown; Debret and Sverjensky, 2017; Chen et al., 2019) with low salinity (5 wt.\% NaCl; Chen et al., 2019) and calculated the partitioning of Mo following the model of Bali et al. (2012). We then employed a 'zone refining' calculation to predict the Mo concentration of the slab fluid as a result of the interaction with a MORB-type oceanic crust during channelized flow through the subducting slab. The proportions of sediments and AMOC in the slab partial melts are the same as those suggested by Freymuth et al. (2016b) and Freymuth et al. (2019). Our calculations are thus in line with previous models reproducing the combined ${ }^{143} \mathrm{Nd} /{ }^{144} \mathrm{Nd},{ }^{176} \mathrm{Hf} /{ }^{177} \mathrm{Hf}$, U-series and stable $\mathrm{U}$ isotope inventory of the Izu arc. Because no Mo data are available for the sedimentary sequence subducting under the Izu arc, we use the average Mo concentration and $\delta^{98 / 95}$ Mo for the sediments at the neighbouring Mariana arc (ODP Sites 801, 801, 802; Freymuth et al., 2015) as the closest approximation. The model parameters are further detailed in Table 2.

Table 2

Input parameters and details of Mo isotopes mixing model for the Izu arc lavas.

\begin{tabular}{|c|c|c|c|c|c|c|c|c|}
\hline & MORB & IM1 & IM2 & Izu sediment & $\begin{array}{l}\text { Sediment } \\
\text { melt }\end{array}$ & AMOC & $\begin{array}{l}\text { AMOC } \\
\text { melt }\end{array}$ & $\begin{array}{l}\text { Aqueous slab } \\
\text { fluid }\end{array}$ \\
\hline Mo $[\mu \mathrm{g} / \mathrm{g}]$ & $0.46^{\mathrm{a}}$ & $0.46^{\mathrm{a}}$ & $0.07^{\mathrm{e}}$ & $2.49^{\mathrm{f}}$ & $9.11^{\mathrm{i}}$ & $0.37^{\mathrm{j}}$ & $1.35^{\mathrm{i}}$ & $2.88^{\mathrm{m}}$ \\
\hline $\mathrm{Hf}[\mu \mathrm{g} / \mathrm{g}]$ & $2.79^{\mathrm{a}}$ & $2.79^{\mathrm{a}}$ & $0.48^{\mathrm{e}}$ & $1.44^{\mathrm{g}}$ & $0.61^{\mathrm{i}}$ & $3.07^{\mathrm{k}}$ & $1.31^{\mathrm{i}}$ & $0^{\mathrm{m}}$ \\
\hline $\mathrm{Nd}[\mu \mathrm{g} / \mathrm{g}]$ & $12.03^{\mathrm{a}}$ & $12.03^{\mathrm{a}}$ & $2.06^{\mathrm{e}}$ & $25.2^{\mathrm{g}}$ & $36.3^{\mathrm{i}}$ & $11.3^{\mathrm{k}}$ & $16.3^{\mathrm{i}}$ & $0.66^{\mathrm{m}}$ \\
\hline$\delta^{98 / 95}$ Mo $(\% o)$ & $-0.2^{\mathrm{b}}$ & $-0.21^{\mathrm{d}}$ & $-0.21^{\mathrm{d}}$ & $-0.29^{\mathrm{f}}$ & $-0.29^{\mathrm{f}}$ & $0.36^{\mathrm{j}}$ & $0.36^{\mathrm{j}}$ & $0.25^{\mathrm{n}}$ \\
\hline${ }^{176} \mathrm{Hf} /{ }^{177} \mathrm{Hf}$ & $0.28326^{\mathrm{c}}$ & 0.28320 & 0.28330 & $0.28290^{\mathrm{h}}$ & $0.28290^{\mathrm{h}}$ & $0.28320^{1}$ & $0.28320^{1}$ & - \\
\hline
\end{tabular}

Slab component

\begin{tabular}{|c|c|c|c|c|c|c|c|c|c|c|}
\hline & $\begin{array}{l}\text { Fluid } \\
(\%)\end{array}$ & $\begin{array}{l}\text { Slab melt } \\
(\%)\end{array}$ & $\begin{array}{l}\text { Sedim. } \\
(\%)\end{array}$ & $\begin{array}{l}\text { AMOC } \\
(\%)\end{array}$ & $\begin{array}{l}\text { Mo }[\mu \mathrm{g} / \\
\mathrm{g}]\end{array}$ & $\begin{array}{l}\mathrm{Hf}[\mu \mathrm{g} / \\
\mathrm{g}]\end{array}$ & $\mathrm{Nd}[\mu \mathrm{g} / \mathrm{g}]$ & $\begin{array}{l}\delta^{98 / 95} \mathrm{Mo} \\
(\% \circ)\end{array}$ & ${ }^{176} \mathrm{Hf} /{ }^{177} \mathrm{Hf}$ & ${ }^{143} \mathrm{Nd} /{ }^{144} \mathrm{Nd}$ \\
\hline $\begin{array}{l}\text { Model } \\
\text { (a) }\end{array}$ & 100 & - & - & - & 2.88 & 0 & 0.66 & 0.25 & - & 0.51312 \\
\hline $\begin{array}{l}\text { Model } \\
\text { (b) }\end{array}$ & 75 & 25 & 5 & 20 & 2.88 & 1.17 & 20.3 & 0.18 & 0.28317 & 0.51288 \\
\hline
\end{tabular}

a Average MORB from Gale et al. (2013).

b Freymuth et al. (2015).

c 'Ambient mantle' for the Izu-Bonin-Mariana arc from Woodhead et al. (2012).

d Depleted mantle from Bezard et al. (2016).

e Trace element content from the sample of D-MORB (i.e. La/Sm $\mathrm{Sm}_{\mathrm{N}}<0.8$ ) with the lowest concentrations from Jenner and O'Neill (2012) chosen to represent melt derived from a highly depleted sub-arc mantle.

f Average Mariana sediment (ODP Sites 800, 801, 802) from Freymuth et al. (2015).

g Average ODP Site 1149 sediment from Plank et al. (2007).

h Bulk composition of ODP Site 1149 sediment from Chauvel et al. (2009)

${ }^{\mathrm{i}}$ Trace element contents of partial melts calculated using partition coefficients from Kessel et al. (2005) at $900{ }^{\circ} \mathrm{C}$, $4 \mathrm{GPa}$ with $\mathrm{F}=0.1$.

${ }^{j}$ ODP Site 801 AMOC super composite from Freymuth et al. (2015).

k ODP Site 801 AMOC super composite from Kelley et al. (2003).

1 Average ODP Site 1149 AMOC from Miyazaki et al. (2015).

$\mathrm{m}$ Trace element content calculated using a 'zone refining' model with rock/fluid ratio of 50 considering a MORB source. Partition coefficient for Mo $\left(\mathrm{D}^{\text {fluid/egt }}=6.26\right)$ calculated after Bali et al. $(2012)$ at $700{ }^{\circ} \mathrm{C}, 2.61 \mathrm{GPa}, \mathrm{FMQ}+4$ and $5 \mathrm{wt} . \% \mathrm{NaCl}$, considering a $2 \mathrm{wt} . \%$ rutile in the source and a Cpx:Gt ratio of 70:30. Partition coefficient for $\mathrm{Nd}$ from Kessel et al. (2005) at $700{ }^{\circ} \mathrm{C}, 4 \mathrm{GPa}$. Fluid was considered free of Hf.

${ }^{n}$ This study. 
Based on the data by Woodhead et al. (2012), we represent the heterogeneity of the Izu sub-arc mantle array as a mixture of two hypothetical mantle end-members in the ${ }^{143} \mathrm{Nd} /{ }^{144} \mathrm{Nd}-{ }^{176} \mathrm{Hf} /{ }^{177} \mathrm{Hf}$ space defined by the Shikoku basin and Mariana Trough basalt array ('IM1' and 'IM2'; see Fig. 7 and Table 2). It is important to note that, in order to reproduce the Mo-Nd-Hf variations of our Izu arc samples, the Izu mantle must not only be heterogeneous in its $\mathrm{Hf}$ and $\mathrm{Nd}$ radiogenic isotope ratios, but also in terms of its trace element content - an assumption that appears easily justifiable. Fig. 8 shows the results of mixing between the sub-arc mantle array described above and: (a) a pure aqueous fluid, and (b) a hydrous slab melt comprising partial melts of subducted sediment and AMOC (i.e. $25 \%$ of the total slab component). The budget of $\mathrm{Hf}$ (and other HFSE) in the arc magmas is largely dominated by the sub-arc mantle. Hafnium is not effectively mobilized in subduction zone fluids (e.g., Pearce et al., 1999), and the Hf isotope ratios of Izu arc magmas have not been significantly modified by the addition of slab-derived melts (e.g.,

\section{a) $100 \%$ aqueous fluid}
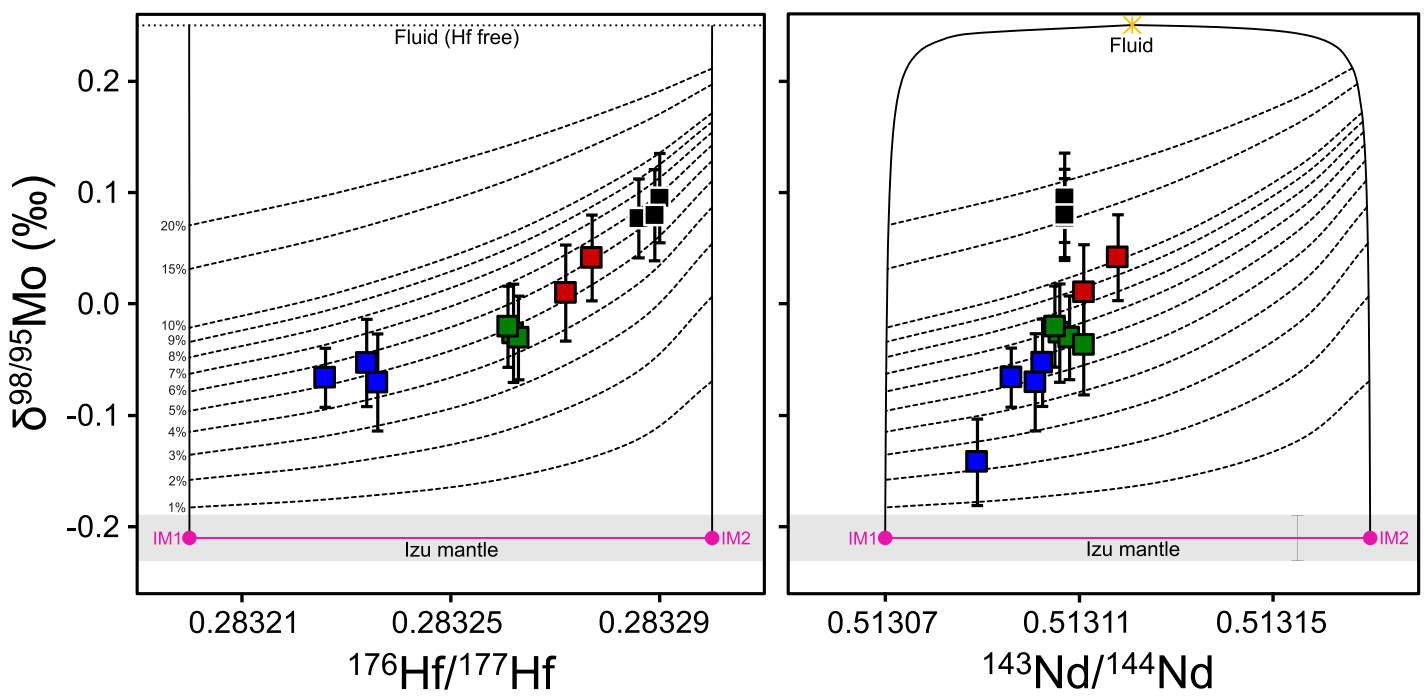

b) $75 \%$ fluid - $25 \%$ slab melt
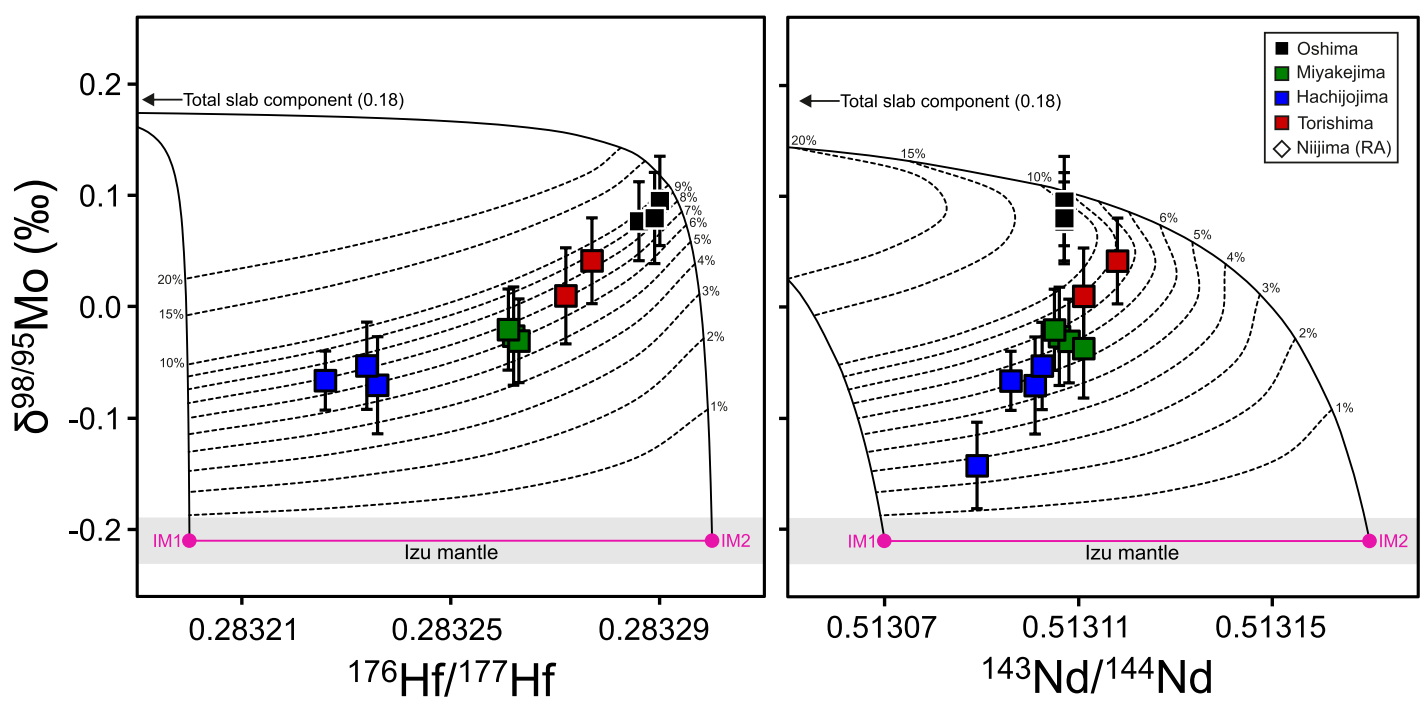

Fig. 8. Mixing models of $\delta^{98 / 95} \mathrm{Mo}-{ }^{176} \mathrm{Hf} /{ }^{177} \mathrm{Hf}-{ }^{143} \mathrm{Nd} /{ }^{144} \mathrm{Nd}$ isotope ratios between the Izu mantle source and (a) an aqueous slab-derived fluid, and (b) a mixed slab component containing sediment and AMOC partial melts. ${ }^{176} \mathrm{Hf} /{ }^{177} \mathrm{Hf}$ and ${ }^{143} \mathrm{Nd} /{ }^{144} \mathrm{Nd}$ isotope data for the Izu arc lavas are from Freymuth et al. (2016b) and are displayed in Table 1. The grey band represents the Mo isotope composition for the depleted mantle (Bezard et al., 2016). IM1 and IM2 are the end-member mantle components used to model the Izu mantle array (see text for details); a mixing line between them is shown in magenta. Black lines at each side are the mixing lines between the mantle end members and the slab component, and dashed lines are contour lines showing the amount of slab component added to the mantle source. End-member compositions and model parameters are detailed in Table 2. 
Chauvel et al., 2009; Freymuth et al., 2016b; Taylor and Nesbitt, 1998). Thus, they directly reflect the Hf isotope composition of the sub-arc mantle. In our ${ }^{176} \mathrm{Hf} /{ }^{177}$ Hf $-\delta^{98 / 95}$ Mo model, the addition of a fluid, either with or without the contribution from slab melts, produces a similar outcome (see Fig. 8). In contrast, the $\mathrm{Nd}$ isotope ratios of the Izu arc lavas are, to some degree, variably affected by slab melt and fluid contributions (Chauvel et al., 2009; Straub et al., 2010). Our ${ }^{143} \mathrm{Nd} /{ }^{144} \mathrm{Nd}-\delta^{98 / 95}$ Mo model suggests that the data for the Izu arc lavas cannot be reproduced with the addition of a slab-derived fluid alone, which would require an unreasonable amount of fluid $(>15 \%$; Fig. 8a) for Oshima samples and is not in agreement with the estimate obtained from our ${ }^{176} \mathrm{Hf} /{ }^{177} \mathrm{Hf}-\delta{ }^{98 / 95} \mathrm{Mo}$ model under the same conditions. A contribution from a slab melt produces an offset in ${ }^{143} \mathrm{Nd} /{ }^{144} \mathrm{Nd}$ that allows the Mo-Nd-Hf isotope variations of our sample set to be reconciled (Fig. 8b). We acknowledge that this is not a unique solution and that the model allows for some variation in the different proportions of slab-derived components but without altering the substance of our interpretations. From the combined Mo-Nd-Hf model, we estimate that a $\sim 5-10 \%$ of slab contribution (of which $75 \%$ comes from fluid, $25 \%$ from a slab melt) is required to explain the Mo isotope variations in the Izu volcanic front lavas. The absolute amount of slab melt component, which encompasses the total contributions from subducted sediments and altered mafic oceanic crust to the arc magmas, is minor (i.e., between $\sim 1.5$ and $2.5 \%$ ). This agrees well with estimates of the absolute contribution from slab melts to the Izu arc magmas determined through modelling with U-series, ${ }^{143} \mathrm{Nd} /{ }^{144} \mathrm{Nd}$ and ${ }^{176} \mathrm{Hf} /{ }^{177} \mathrm{Hf}(<2-6 \%$; Chauvel et al., 2009; Freymuth et al., 2016b).

The results above not only reinforce the notion that fluid addition to the sub-arc mantle has had an influence on the chemical and isotopic composition of the corresponding arc lavas, but moreover give detailed insights into the mantle heterogeneity beneath the Izu arc. Our calculations suggest that, while the lavas from Oshima require a higher input of slab-derived fluids, which could increase melting in the mantle wedge, large (arc-length) scale compositional variation of the Izu mantle source is still required to explain the Mo-Nd-Hf systematics of the Izu arc lavas. The Mo isotope signature of arc magmas thus not only depends on the capability of the subduction zone fluids to incorporate and transport Mo from the oceanic crust to the sub-arc mantle, but also on the Mo concentration contrast between the mantle and the fluid transferred from the slab, which may be a function of prior mantle depletion.

\subsection{The Mo mass balance in subduction zones}

The loss of isotopically heavy Mo in fluids during subduction implies that the eclogitic slabs that are recycled into the deep convecting mantle should carry a complementary Mo budget that is depleted in heavy Mo isotopes relative to MORB. In order to quantify this, Freymuth et al. (2015) carried out a Mo mass balance in the Mariana arc wherein they inferred a $\delta^{98 / 95} \mathrm{Mo}$ of -0.36 to $-0.27 \%$ for the residual slab. Using the same approach, we provide a refined mass balance calculation for the Izu arc in order to more accurately constrain the effects of Mo removal from the slab on its Mo isotopic composition. All parameters and details of the calculations are presented in the supplementary material (Table S1). The slab currently subducting under the Izu arc carries approximately $292 \mathrm{~kg} / \mathrm{km}$ of Mo per year into the subduction zone, whereas the Mo output from the arc in arc magmas is approximately $151 \mathrm{~kg} / \mathrm{km}$ per year. According to the proportions of slab components added to the sub-arc mantle source (see Fig. 8b), approximately $55 \%$ of the Mo budget in the Izu arc lavas is slab-derived. When contrasted with the Mo flux into the Izu subduction zone, this implies that about $29 \%$ of the Mo contained in the subducting slab is removed at arc-depth and added to the overlying mantle. The average Mo isotope composition of the material removed from the slab (i.e. hydrous fluid and partial melts of sediment and AMOC) is $\delta^{98 / 95} \mathrm{Mo}=\sim 0.18 \%$ (see Table 2). Accordingly, the residual eclogitic slab should have a Mo isotope composition of approximately $\delta^{98 / 95} \mathrm{Mo}=-0.35 \%$ after subduction modification. This is well within the range of reported data for eclogites $\left(\delta^{98 / 95} \mathrm{Mo}=-0.45 \pm 0.25 \%\right.$; $\mathrm{N}=14,2 \mathrm{SD}$; Chen et al. 2019). We note that the approach above only considers the Mo transferred from the slab to the mantle wedge recorded through arc magmatism. It is thus a conservative estimate of the magnitude of Mo loss during subduction, and therefore the modifications to the Mo budget and isotope composition of the subducting slab could potentially be greater.

\section{CONCLUSIONS}

The Izu arc lavas reveal relative enrichments in Mo abundances and some of the highest $\delta^{98 / 95}$ Mo reported to date for island arc basalts, being ubiquitously isotopically heavier than MORB. Heavy Mo isotope ratios in the Izu arc lavas are associated with fluid-mobile trace element enrichments and U-excess, suggesting that isotopically heavy Mo is transferred to the source of the Izu arc magmas via slab-derived fluids, for which we estimate a $\delta^{98 / 95} \mathrm{Mo}$ of $0.1-0.25 \%$. Furthermore, co-variations between Mo isotope ratios and ${ }^{143} \mathrm{Nd} /{ }^{144} \mathrm{Nd}$ as well as ${ }^{176} \mathrm{Hf} /{ }^{177} \mathrm{Hf}$ isotope ratios suggest a causal connection between the degree of mantle depletion and compositional variations due to fluid contribution in the lavas from the Izu volcanic front. Our calculations suggest that the compositional variations in the Izu arc lavas can be reproduced by addition of a fluid-dominated slab component to a mantle source isotopically and chemically heterogeneous on an arc-length scale. Slab-derived fluid contributions appear to be more strongly reflected in magmas originating from highly depleted mantle domains. This could be the result of variations in the composition of the mantle wedge along the arc, enhancing the effect of aqueous fluids on the Mo budget of arc magmas with more depleted mantle sources, coupled with increased melting of the sub-arc mantle due to a relatively higher fluid flux.

Our results lend strong support to the notion that Mo isotope fractionation occurs during the release of fluids 
and their movement through the oceanic crust, whereby residual rutile retains isotopically light $\mathrm{Mo}$ in eclogites. The refractory slab that sinks into the deep mantle carries an isotopically light Mo signature of $\delta^{98 / 95} \mathrm{Mo} \sim-0.35 \%$, according to our conservative estimate, which appears to agree with current estimates for the Mo isotope composition of eclogites. Although further work is required to complete the mass balance of Mo isotopes in subduction zones, our data provide strong evidence for a complementary signature between arc magmas and eclogitic slab residues. The modification of the Mo isotope composition of the oceanic crust during subduction has important implications for the global cycle of Mo, as the residual slabs carry isotopically light Mo into the deeper mantle. Consequently, low $\delta^{98 / 95}$ Mo measured in OIB and other intraplate magmas might be fingerprinting recycled crustal material in the mantle, which would provide a new perspective with which to investigate deep mantle recycling of subducted oceanic lithosphere and associated magma petrogenesis.

\section{Declaration of Competing Interest}

The authors declare that they have no known competing financial interests or personal relationships that could have appeared to influence the work reported in this paper.

\section{ACKNOWLEDGEMENTS}

We thank M. Brounce, Y. Zhang, an anonymous reviewer and Associate Editor S. Huang for their positive comments and suggestions, which helped us to improve the manuscript. We thank C. Coath and R. Hin for their assistance and advice during our double spike calibrations. JVO acknowledges funding from the National Agency for Research and Development (ANID)/Scholarship Program/DOCTORADO BECAS CHILE/2016 - 72170390 for the development of this work as part of her $\mathrm{PhD}$ program. HF acknowledges funding from a Leverhulme Trust Early Career Fellowship (RG95456) and from the Isaac Newton Trust. MW acknowledges funding from Natural Environment Research Council (NERC) Advanced Research Fellowship NE/J018031/2, and MW and BO'D acknowledge support from NERC Standard Grant NE/L004011/1.

\section{APPENDIX A. SUPPLEMENTARY MATERIAL}

Supplementary data to this article can be found online at https://doi.org/10.1016/j.gca.2020.07.043.

\section{REFERENCES}

Bali E., Keppler H. and Audetat A. (2012) The mobility of W and Mo in subduction zone fluids and the Mo-W-Th-U systematics of island arc magmas. Earth Planet. Sci. Lett. 351-352, 195207.

Barling J., Arnold G. L. and Anbar A. D. (2001) Natural massdependent variations in the isotopic composition of molybdenum. Earth Planet. Sci. Lett. 193, 447-457.

Bezard R., Fischer-Godde M., Hamelin C., Brennecka G. A. and Kleine T. (2016) The effects of magmatic processes and crustal recycling on the molybdenum stable isotopic composition of Mid-Ocean Ridge Basalts. Earth Planet. Sci. Lett. 453, 171-181.
Burkhardt C., Hin R. C., Kleine T. and Bourdon B. (2014) Evidence for Mo isotope fractionation in the solar nebula and during planetary differentiation. Earth Planet. Sci. Lett. 391, 201-211.

Carter L. B., Skora S., Blundy J. D., De Hoog J. C. M. and Elliot T. (2015) An experimental study of trace element fluxes from subducted oceanic crust. J. Petrol. 56(8), 1585-1606.

Casalini M., Avanzinelli R., Tommasini S., Elliott T. and Conticelli S. (2019) Ce/Mo and molybdenum isotope systematics in subduction-related orogenic potassic magmas of CentralSouthern Italy. Geochem. Geophys. Geosyst. 20(6), 2753-2768.

Chauvel C., Marini J. C., Plank T. and Ludden J. N. (2009) Hf-Nd input flux in the izu-mariana subduction zone and recycling of subducted material in the mantle. Geochem. Geophys. Geosyst. 10(1).

Chen S., Hin R. C., John T., Brooker R., Bryan B., Niu Y. and Elliott T. (2019) Molybdenum systematics of subducted crust record reactive fluid flow from underlying slab serpentine dehydration. Nat. Commun., 10.

Davidson J., Turner S., Handley H., Macpherson C. and Dosseto A. (2007) Amphibole "sponge" in arc crust? Geology 35, 787790.

Debret B. and Sverjensky D. A. (2017) Highly oxidising fluids generated during serpentinite breakdown in subduction zones. Sci. Rep. 7(1), 1-6.

Elliott T., Plank T., Zindler A., White W. and Bourdon B. (1997) Element transport from slab to volcanic front at the Mariana arc. J. Geophys. Res. Solid Earth 102, 14991-15019.

Freymuth H., Andersen M. B. and Elliott T. (2019) Uranium isotope fractionation during slab dehydration beneath the Izu arc. Earth Planet. Sci. Lett. 522, 244-254.

Freymuth H., Elliott T., van Soest M. and Skora S. (2016a) Tracing subducted black shales in the Lesser Antilles arc using molybdenum isotope ratios. Geology 44, 987-990.

Freymuth H., Ivko B., Gill J. B., Tamura Y. and Elliott T. (2016b) Thorium isotope evidence for melting of the mafic oceanic crust beneath the Izu arc. Geochim. Cosmochim. Acta 186, 49-70.

Freymuth H., Vils F., Willbold M., Taylor R. N. and Elliott T. (2015) Molybdenum mobility and isotopic fractionation during subduction at the Mariana arc. Earth Planet. Sci. Lett. 432, 176-186.

Fukuda S., Nakai S., Niihori K., Tsukui M., Nakada S., Fujii T. and Tani K. (2008) 238U-230Th radioactive disequilibrium in the northern Izu arc: $(230 \mathrm{Th} / 232 \mathrm{Th})$ in the sub-arc mantle. Geochem. J. 42, 461-479.

Gale A., Dalton C. A., Langmuir C. H., Su Y. and Schilling J. G. (2013) The mean composition of ocean ridge basalts. Geochem. Geophys. Geosyst. 14, 489-518.

Gaschnig R. M., Reinhard C. T., Planavsky N. J., Wang X., Asael D. and Chauvel C. (2017) The molybdenum isotope system as a tracer of slab input in subduction zones: an example from Martinique, Lesser Antilles Arc. Geochem. Geophys. Geosyst. 18, 46744689.

Gill J. B. (1981) Bulk chemical composition of orogenic andesites. In Orogenic Andesites and Plate Tectonics, vol. 16, pp. 97-167. Orogenic Andesites and Plate Tectonics. Springer, Berlin, Heidelberg.

Green T. H. and Adam J. (2003) Experimentally-determined trace element characteristics of aqueous fluid from partially dehydrated mafic oceanic crust at $3.0 \mathrm{GPa}, 650-700^{\circ} \mathrm{C}$. Eur. J. Mineral. 15, 815-830.

Hawkesworth C. J., Hergt J. M., Ellam R. M. and McDermott F. (1991) Element fluxes associated with subduction related magmatism. Philos. Trans. - R. Soc. Lond. 335, 393-405.

Hochstaedter A. G., Gill J. B., Taylor B., Ishizuka O., Yuasa M. and Monta S. (2000) Across-arc geochemical trends in the Izu- 
Bonin arc: Constraints on source composition and mantle melting. J. Geophys. Res. Solid Earth 105, 495-512.

Hochstaedter A., Gill J., Peters R., Broughton P., Holden P. and Taylor B. (2001) Across-arc geochemical trends in the IzuBonin arc: Contributions from the subducting slab. Geochem. Geophys. Geosyst. 2(7).

Imai N., Terashima S., Itoh S. and Ando A. (1995) 1994 Compilation of analytical data for minor and trace elements in seventeen GSJ geochemical reference samples, "Igneous Rock Series". Geostand. Newsl. 19, 135-213.

Ishizuka O., Geshi N., Itoh J., Kawanabe Y. and TuZino T. (2008) The magmatic plumbing of the submarine Hachijo NW volcanic chain, Hachijojima, Japan: Long-distance magma transport? J. Geophys. Res. Solid Earth 113(B8).

Isse T., Shiobara H., Tamura Y., Suetsugu D., Yoshizawa K., Sugioka H., Ito A., Kanazawa T., Shinohara M., Mochizuki K., Araki E., Nakahigashi K., Kawakatsu H., Shito A., Fukao Y., Ishizuka O. and Gill J. B. (2009) Seismic structure of the upper mantle beneath the Philippine Sea from seafloor and land observation: Implications for mantle convection and magma genesis in the Izu-Bonin-Mariana subduction zone. Earth Planet. Sci. Lett. 278, 107-119.

Jenner F. E. and O'Neill H. S. C. (2012) Analysis of 60 elements in 616 ocean floor basaltic glasses. Geochem. Geophys. Geosyst. 13 (2).

Kelley K. A., Plank T., Ludden J. and Staudigel H. (2003) Composition of altered oceanic crust at ODP Sites 801 and 1149. Geochem. Geophys. Geosyst. 4(6).

Kessel R., Schmidt M. W., Ulmer P. and Pettke T. (2005) Trace element signature of subduction-zone fluids, melts and supercritical liquids at 120-180 km depth. Nature 437, 724-727.

Kimura J.-I., Kent A. J. R., Rowe M. C., Katakuse M., Nakano F., Hacker B. R., Van Keken P. E., Kawabata H. and Stern R. J. (2010) Origin of cross-chain geochemical variation in Quaternary lavas from the northern Izu arc: Using a quantitative mass balance approach to identify mantle sources and mantle wedge processes. Geochem. Geophys. Geosyst. 11(10).

Klimm K., Blundy J. D. and Green T. (2008) Trace element partitioning and accessory phase saturation during $\mathrm{H}_{2} \mathrm{O}$-saturated melting of basalt with implications for subduction zone chemical fluxes. J. Petrol. 49(3), 523-553.

König S., Münker C., Schuth S., Luguet A., Hoffmann J. E. and Kuduon J. (2010) Boninites as windows into trace element mobility in subduction zones. Geochim. Cosmochim. Acta 74, 684-704.

König S., Wille M., Voegelin A. and Schoenberg R. (2016) Molybdenum isotope systematics in subduction zones. Earth Planet. Sci. Lett. 447, 95-102.

Miller D. M., Goldstein S. L. and Langmuir C. H. (1994) Cerium lead and lead-isotope ratios in arc magmas and the enrichment of lead in the continents. Nature 368, 514-520.

Miyazaki T., Kimura J.-I., Senda R., Vaglarov B. S., Chang Q., Takahashi T., Hirahara Y., Hauff F., Hayasaka Y., Sano S., Shimoda G., Ishizuka O., Kawabata H., Hirano N., Machida S., Ishii T., Tani K. and Yoshida T. (2015) Missing western half of the Pacific Plate: Geochemical nature of the Izanagi-Pacific Ridge interaction with a stationary boundary between the Indian and Pacific mantles. Geochem. Geophys. Geosyst. 16, 3309-3332.

Newsom H. E. and Palme H. (1984) The depletion of siderophile elements in the Earth's mantle: new evidence from molybdenum and tungsten. Earth Planet. Sci. Lett. 69, 354-364.

Newsom H. E., White W. M., Jochum K. P. and Hofmann A. W. (1986) Siderophile and chalcophile element abundances in oceanic basalts, $\mathrm{Pb}$ isotope evolution and growth of the Earth's core. Earth Planet. Sci. Lett. 80, 299-313.
Pearce J. A., Kempton P. D., Nowell G. M. and Noble S. R. (1999) Hf-Nd element and isotope perspective on the nature and provenance of mantle and subduction components in Western Pacific Arc-basin systems. J. Petrol. 40, 1579-1611.

Plank T., Kelley K. A., Murray R. W. and Stern L. Q. (2007) Chemical composition of sediments subducting at the IzuBonin trench. Geochem. Geophys. Geosyst. 8(4).

Rudge J. F., Reynolds B. C. and Bourdon B. (2009) The double spike toolbox. Chem. Geol. 265, 420-431.

Rustioni G., Audétat A. and Keppler H. (2019) Experimental evidence for fluid-induced melting in subduction zones. Geochem. Perspect. Lett. 11, 49-54.

Siebert C., Nägler T. F. and Kramers J. D. (2001) Determination of Mo isotope fractionation by double-spike multicollector inductively coupled plasma mass spectrometry. Geochem. Geophys. Geosyst. 2(7).

Skora S. and Blundy J. D. (2010) High-pressure hydrous phase relations of radiolarian clay and implications for the involvement of subducted sediment in arc magmatism. J. Petrol 51(11), 2211-2243.

Skora S., Freymuth H., Blundy J., Elliott T. and Guillong M. (2017) An experimental study of the behaviour of cerium/molybdenum ratios during subduction: Implications for tracing the slab component in the Lesser Antilles and Mariana Arc. Geochim. Cosmochim. Acta 212, 133-155.

Spandler C. and Pirard C. (2013) Element recycling from subducting slabs to arc crust: A review. Lithos 170-171, 208223.

Straub S. M., Goldstein S. L., Class C., Schmidt A. and GomezTuena A. (2010) Slab and mantle controls on the Sr-Nd-Pb-Hf isotope evolution of the Post $42 \mathrm{Ma}$ Izu-Bonin volcanic arc. $J$. Petrol. 51, 993-1026.

Tamura Y., Tani K., Chang Q., Shukuno H., Kawabata H., Ishizuka O. and Fiske R. S. (2007) Wet and dry basalt magma evolution at Torishima volcano, Izu-Bonin arc, Japan: The possible role of phengite in the downgoing slab. J. Petrol. 48, 1999-2031.

Taylor R. N. and Nesbitt R. W. (1998) Isotopic characteristics of subduction fluids in an intra-oceanic setting, Izu-Bonin Arc, Japan. Earth Planet. Sci. Lett. 164, 79-98.

Tollstrup D., Gill J., Kent A., Prinkey D., Williams R., Tamura Y. and Ishizuka O. (2010) Across-are geochemical trends in the Izu-Bonin arc: Contributions from the subducting slab, revisited. Geochem. Geophys. Geosyst. 11(1).

Ulmer P. and Trommsdorff V. (1995) Serpentine stability to mantle depths and subduction-related magmatism. Science (80-.) 268, 858-861.

Voegelin A. R., Pettke T., Greber N. D., von Niederhäusern B. and Nägler T. F. (2014) Magma differentiation fractionates Mo isotope ratios: Evidence from the Kos Plateau Tuff (Aegean Arc). Lithos 190-191, 440-448.

Willbold M. and Elliott T. (2017) Molybdenum isotope variations in magmatic rocks. Chem. Geol. 449, 253-268.

Willbold M., Hibbert K., Lai Y. J., Freymuth H., Hin R. C., Coath C., Vils F. and Elliott T. (2016) High-precision mass-dependent molybdenum isotope variations in magmatic rocks determined by double-spike MC-ICP-MS. Geostand. Geoanal. Res. 40, 389-403.

Wille M., Nebel O., Pettke T., Vroon P. Z., König S. and Schoenberg R. (2018) Molybdenum isotope variations in calcalkaline lavas from the Banda arc, Indonesia: Assessing the effect of crystal fractionation in creating isotopically heavy continental crust. Chem. Geol. 485, 1-13.

Woodhead J., Stern R. J., Pearce J., Hergt J. and Vervoort J. (2012) Hf-Nd isotope variation in Mariana Trough basalts: The importance of "ambient mantle" in the interpretation of subduction zone magmas. Geology 40, 539-542. 
Yang J., Siebert C., Barling J., Savage P., Liang Y. H. and Halliday A. N. (2015) Absence of molybdenum isotope fractionation during magmatic differentiation at Hekla volcano, Iceland. Geochim. Cosmochim. Acta 162, 126-136.

Zhang L., Li J., Xu Y.-G. and Ren Z.-Y. (2018) The influence of the double spike proportion effect on stable isotope $(\mathrm{Zn}, \mathrm{Mo}$, $\mathrm{Cd}$, and $\mathrm{Sn}$ ) measurements by multicollector-inductively coupled plasma-mass spectrometry (MC-ICP-MS). J. Anal. At. Spectrom. 33, 555-562.
Zhang Y., Yuan C., Sun M., Li J., Long X., Jiang Y. and Huang Z. (2020) Molybdenum and boron isotopic evidence for carbonrecycling via carbonate dissolution in subduction zones. Geochim. Cosmochim. Acta 278, 340-352.

Associate editor: Shichun Huang 